\title{
Tissue Engineering and Regenerative Medicine
}

\section{Novel injectable gellan gum hydrogel composites incorporating $\mathbf{Z n}$ - and Sr-enriched bioactive glass microparticles: high-resolution X-Ray micro-computed tomography, antibacterial and in vitro testing}

\begin{tabular}{|c|c|}
\hline Journal: & Journal of Tissue Engineering and Regenerative Medicine \\
\hline Manuscript ID & TERM-17-0068.R1 \\
\hline Wiley - Manuscript type: & Research Article \\
\hline Date Submitted by the Author: & 31-Oct-2017 \\
\hline Complete List of Authors: & $\begin{array}{l}\text { Douglas, Timothy; Lancaster University, Engineering } \\
\text { Dziadek, Michal; AGH University of Science and Technology, Glass } \\
\text { Technology and Amorphous Coatings } \\
\text { Gorodha, Svetlana; National Research Tomsk Polytechnic University, } \\
\text { Theoretical and Experimental Physics } \\
\text { Liskova, Jana; Institute of Physiology, Academy of Sciences of the Czech } \\
\text { Republic, Department of Biomaterials and Tissue Engineering } \\
\text { Brackman, Gilles; University of Gent, Laboratory of Pharmaceutical } \\
\text { Microbiology } \\
\text { Vanhoorne, Valerie; Ghent University, Laboratory of Pharmaceutical } \\
\text { Technology, Department of Pharmaceutics, Faculty of Pharmaceutical } \\
\text { Sciences, } \\
\text { Vervaet, Chris; Ghent University, Laboratory of Pharmaceutical } \\
\text { Technology, Department of Pharmaceutics, Faculty of Pharmaceutical } \\
\text { Sciences, } \\
\text { Balcaen, Lieve; Ghent University, Department of Analytical Chemistry } \\
\text { del Rosario Florez Garcia, Maria ; Ghent University, Laboratory of } \\
\text { Pharmaceutical Technology, Department of Pharmaceutics, Faculty of } \\
\text { Pharmaceutical Sciences, } \\
\text { Boccaccini, Aldo; University of Erlangen-Nuremberg, Institute of } \\
\text { Biomaterials, Dept. Materials Science and Engineering } \\
\text { Weinhardt, Venera; University of Heidelberg, Centre for Organismal } \\
\text { Studies } \\
\text { Baumbach, Tilo; Karlsruhe Institute of Technology, Laboratory for } \\
\text { Applications of Synchrotron Radiation, } \\
\text { Vanhaecke, Frank; Ghent University, Department of Analytical Chemistry } \\
\text { Coenye, Tom; University of Gent, Laboratory of Pharmaceutical } \\
\text { Microbiology } \\
\text { Bacakova, Lucie; Institute of Physiology, Academy of Sciences of the Czech } \\
\text { Republic, Department of Biomaterials and Tissue Engineering } \\
\text { Surmeneva, Maria; National Research Tomsk Polytechnic University, } \\
\text { Theoretical and Experimental Physics } \\
\text { Surmenev, Roman; Tomsk Polytechnic University, Russia, The Centre of } \\
\text { Technology } \\
\text { Cholewa-Kowalska, Katarzyna; AGH University of Science and Technology, }\end{array}$ \\
\hline
\end{tabular}


Keywords: bioactive glass, hydrogel, composite, bone, $\mu \mathrm{CT}$, antibacterial, injectable

SCHOLARONE
Manuscripts 


\section{Novel injectable gellan gum hydrogel composites incorporating Zn-and Sr-enriched}

bioactive glass microparticles: high-resolution X-Ray micro-computed tomography, antibacterial and in vitro testing

Timothy E.L. Douglas ${ }^{1,2,3 *}$, Michal Dziadek ${ }^{4}$, Svetlana Gorodzha ${ }^{5}$, Jana Lišková ${ }^{6}$, Gilles Brackman $^{7}$, Valérie Vanhoorne ${ }^{8}$, Chris Vervaet $^{8}$, Lieve Balcaen $^{9}, \underline{\text { Maria del Rosario Florez }}$ Garcia $^{9}$, Aldo R. Boccaccini ${ }^{10}$, Venera Weinhardt ${ }^{11}$, Tilo Baumbach ${ }^{12}$, Frank Vanhaecke ${ }^{9}$, Tom Coenye ${ }^{7}$, Lucie Bačáková ${ }^{6}$, Maria A. Surmeneva ${ }^{5}$, Roman A. Surmenev ${ }^{5,13}$, Katarzyna Cholewa-Kowalska ${ }^{4}$, Andre G. Skirtach ${ }^{1,14}$

${ }^{1}$ Dept. Molecular Biotechology, Ghent University, Coupure Links 653, 9000 Gent, Belgium, ${ }^{2}$ Engineering Dept., Lancaster University, United Kingdom, ${ }^{3}$ Materials Science Institute (MSI), Lancaster University, United Kingdom, ${ }^{4}$ Dept. Glass Technology and Amorphous Coatings, AGH University of Science and Technology, Krakow, Poland, ${ }^{5}$ Dept. Theoretical and Experimental Physics, National Research Tomsk Polytechnic University, Russia, ${ }^{6}$ Dept.

Biomaterials and Tissue Engineering, Institute of Physiology of the Czech Academy of Sciences, Videnska 1083, 14220 Prague 4 - Krc, Czech Republic, ${ }^{7}$ Laboratory of Pharmaceutical Microbiology, Department of Pharmaceutical Analysis, Faculty of Pharmaceutical Sciences, Ghent University, Ottergemsesteenweg 460, 9000 Gent, Belgium,

${ }^{8}$ Laboratory of Pharmaceutical Technology, Department of Pharmaceutics, Faculty of Pharmaceutical Sciences, Ghent University, Ottergemsesteenweg 460, 9000 Gent, Belgium,

${ }^{9}$ Dept. Analytical Chemistry, Ghent University, Krijgslaan 281 S12, 9000 Ghent, Belgium,

${ }^{10}$ Institute of Biomaterials, Dept. Materials Science and Engineering, University of ErlangenNuremberg, Cauerstr. 6, 91058 Erlangen, Germany, ${ }^{11}$ Centre for Organismal Studies, University of Heidelberg, Heidelberg, Germany, ${ }^{12}$ Laboratory for Applications of Synchrotron Radiation and Institute for Photon Science and Synchrotron Radiation, Karlsruhe 
Institute of Technology, Karlsruhe, Germany, ${ }^{13}$ Fraunhofer Institute for Interfacial

Engineering and Biotechnology IGB, Stuttgart, Germany, ${ }^{14}$ Centre for Nano- and

Biophotonics, Ghent University, 9000 Ghent, Belgium.

*Corresponding Author. Email: t.douglas@lancaster.ac.uk

Short title: Novel gellan gum hydrogel-bioactive glass injectable composites

\begin{abstract}
Mineralization of hydrogel biomaterials is desirable to improve their suitability as materials for bone regeneration. In this study, gellan gum (GG) hydrogels were formed by simple mixing of GG solution with bioactive glass microparticles of $45 \mathrm{~S} 5$ composition, leading to hydrogel formation by ion release from the amorphous bioactive glass microparticles. This resulted in novel injectable, self-gelling composites of GG hydrogels containing $20 \%$ bioactive glass. Gelation occurred within 20 minutes. Composites containing the standard 45S5 bioactive glass preparation were markedly less stiff. X-ray $\mu \mathrm{CT}$ proved to be a highly sensitive technique capable of detecting microparticles of diameter approximately $8 \mu \mathrm{m}$, i.e. individual microparticles, and accurately visualizing the size distribution of bioactive glass microparticles and their aggregates, and their distribution in GG hydrogels. The widely used melt-derived 45S5 preparation served as a standard and was compared to a calcium-rich, solgel derived preparation (A2), as well as A2 enriched with zinc (A2Zn5) and strontium (A2Sr5).A2, A2Zn and A2Sr bioactive glass particles were more homogeneously dispersed in GG hydrogels than 45S5. Composites containing all four bioactive glass preparations exhibited antibacterial activity against methicillin-resistant Staphylococcus aureus (MRSA). Composites containing $\mathrm{A} 2 \mathrm{Zn} 5$ and $\mathrm{A} 2 \mathrm{Sr} 5$ bioactive glasses supported the adhesion and growth of osteoblast-like cells and were considerably more cytocompatible than 45S5. All composites underwent mineralization with calcium-deficient hydroxyapatite (CDHA) upon
\end{abstract}


incubation in simulated body fluid (SBF). The extent of mineralization appeared to be greatest for composites containing A2Zn5 and 45S5. The results underline the importance of the choice of bioactive glass when preparing injectable, self-gelling composites. 


\section{Introduction}

Gellan gum (GG) is an inexpensive anionic polysaccharide produced biotechnologically using bacteria, from which hydrogels can be formed by crosslinking with divalent ions such as $\mathrm{Ca}^{2+}$. In order to improve the suitability of hydrogels for applications in bone regeneration, various strategies have been employed to enrich hydrogels with a mineral phase (Gkioni et al., 2010), most commonly a form of calcium phosphate $(\mathrm{CaP})$ which is desirable to promote bioactivity, i.e. a material's capability to bond directly to bone tissue (LeGeros, 1991). The presence of $\mathrm{CaP}$ also promotes adhesion and proliferation of bone-forming cells in vitro and reinforces the hydrogel mechanically (Douglas et al., 2014a).

The most common strategy to incorporate minerals is the addition of preformed inorganic particles. Several groups have incorporated microparticles of bioactive glass, (BG), especially the $45 \mathrm{~S} 5$ formulation (composition in $\mathrm{wt} \%$ : $45 \mathrm{SiO}_{2}, 24.5 \mathrm{CaO}, 24.5 \mathrm{Na}_{2} \mathrm{O}$, and $6 \mathrm{P}_{2} \mathrm{O}_{5}$ ) (Hench, 1998), into hydrogels, and subsequently incubated the resulting composites in simulated body fluid (SBF) to induce CaP formation (Marelli et al., 2010) . Upon incubation in SBF, an apatite forms on the surface of bioactive glasses, resulting in bioactivity (Jones, 2013).

A further advantage of using bioactive glasses is their high amorphousness and ability to release $\mathrm{Ca}^{2+}$ to crosslink GG and induce GG hydrogel formation (Douglas et al., 2014b, Gorodzha et al., 2016). Such composites can be implanted in a minimally-invasive fashion by injection.

Other advantages of bioactive glasses include their antibacterial properties, both alone and as components of hydrogel-bioactive glass composites (Allan et al., 2001, Douglas et al., 2014b, 
Gubler et al., 2008, Hu et al., 2009) and, since bioactive glasses are amorphous in nature, straightforward incorporation of metal ions and therapeutic drugs. These can influence cell behavior and impart antibacterial activity (Hoppe et al., 2011, Hum and Boccaccini, 2012).

Two such metal ions relevant in bone regeneration have been incorporated into bioactive glasses: zinc (Zn) and strontium (Sr). Previously, it was revealed that inorganic biomaterials enriched with $\mathrm{Zn}$ demonstrate antibacterial properties (Douglas et al., 2015), while Srenriched inorganic biomaterials have been reported to promote osteoblast proliferation and differentiation (Boanini et al., 2012).

The aim of the present study was the generation of novel, self-gelling, injectable hydrogelbioactive glass composites by simple addition of bioactive glass microparticles to GG solution, resulting in hydrogel formation. The bioactive glass type studied was a Ca-rich preparation derived by a sol-gel process, hereafter referred to as A2. In previous work, A2 was enriched with $\mathrm{Sr}$, and incorporated into solid polymer scaffolds, leading to improved cell proliferation (Dziadek et al., 2016). In the present study, A2 was enriched either with $\mathrm{Sr}$ or with $\mathrm{Zn}$ to create novel compositions, hereafter referred to as $\mathrm{A} 2 \mathrm{Sr} 5$ and $\mathrm{A} 2 \mathrm{Zn} 5$, respectively. The widely used melt-derived 45S5 preparation was also included as a reference material.

It was hypothesized that the composition of the bioactive glass preparation would influence:

(i) the speed of gelation of the GG hydrogel to form the hydrogel-bioactive glass composite and the viscoelastic properties of the composite;

(ii) the homogeneity of the distribution of the bioactive glass within the composite;

(iii) the composites' antibacterial activity;

(iv) the adhesion and proliferation of osteoblast-like cells seeded on the composites and 
(v) the extent of mineral formation upon incubation of the composites in simulated body fluid (SBF).

Bioactive glass microparticles were characterized by laser diffraction. The speed of gelation of hydrogel-bioactive glass composites and their viscoelastic properties were studied by rheometry. X-ray micro-computed tomography $(\mu \mathrm{CT})$ analysis of composites was performed. This advanced technique not only enables the distribution of bioactive glass microparticles and aggregates in hydrogels to be studied, but also evaluation of the sizes of aggregates. This high-resolution technique is applicable in the wet state, unlike other high-resolution techniques such as electron microscopy.

Biological characterization involved assessment of the cytocompatibility of the composites and their ability to promote the adhesion and proliferation of osteoblast-like cells, as well as their antibacterial properties towards methicillin-resistant Staphylococcus aureus (MRSA).

Staphylococcus aureus is the most commonly occurring in orthopedic healthcare-related infections. MRSA is particularly problematic due to its resistance to certain antibiotics. It is $\underline{\text { desirable that a material for bone regeneration exhibits antibacterial activity as a preventative }}$ $\underline{\text { measure to combat bone infection, or osteomyelitis. MRSA are known to commonly appear }}$ on skin but can cause infections in bone defect sites and broken bones, especially if the patient's immune system is weakened. MRSA can spread to bones by invading a severe injury, deep cut, or wound near to a bone defect, or by entering at another site and migrating to the bone defect via the blood stream.

Physicochemical characterization after incubation in SBF involved determination of the amount, morphology and nature of mineral formed by Fourier-transform infrared 
spectroscopy (FTIR), scanning electron microscopy (SEM) and inductively coupled plasma optical emission spectroscopy (ICP-OES).

\section{Materials and Methods}

\subsection{Materials}

All materials, including GG (Gelzan TM CM, Product no. G1910, "Low-Acyl”, molecular weight 200-300 kD), were obtained from Sigma-Aldrich, unless stated otherwise.

\subsection{Bioactive glass particle synthesis and characterization}

\subsubsection{Bioactive glass synthesis}

The A2, A2Sr5, and A2Zn5 bioactive glasses were produced by a sol-gel method as described previously (Laczka et al., 2000). Chemical compositions of obtained bioactive glasses are presented in Table 1. Tetraethyl orthosilicate (TEOS, $\left.\mathrm{Si}\left(\mathrm{OC}_{2} \mathrm{H}_{5}\right)_{4}\right)$, triethyl phosphate (TEP, OP( $\left.\left(\mathrm{OC}_{2} \mathrm{H}_{5}\right)_{3}\right)$, calcium nitrate tetrahydrate $\left(\mathrm{Ca}\left(\mathrm{NO}_{3}\right)_{2} \cdot 4 \mathrm{H}_{2} \mathrm{O}\right)$, strontium nitrate $\left(\mathrm{Sr}\left(\mathrm{NO}_{3}\right)_{2}\right)$, and zinc nitrate $\left(\mathrm{Zn}\left(\mathrm{NO}_{3}\right)_{2}\right)$ (POCh, Poland), were used as the starting materials. Ethanol (96\%; POCh, Poland) was used as a solvent and $\mathrm{HCl}$ solution (POCH, Poland) was applied as a catalyst of the hydrolysis and polycondensation reactions. Obtained solutions were left at the ambient conditions until gels were formed. After drying at $80{ }^{\circ} \mathrm{C}$, gels were heated up to $700{ }^{\circ} \mathrm{C}$ and kept at this temperature for $20 \mathrm{~h}$. The gel-derived materials were then milled and sieved to obtain grain size $<45 \mu \mathrm{m}$

Melt-derived standard bioactive glass powder of composition 45S5 was obtained from the company Schott AG, Germany. This glass is fabricated by a melting technique which results, after milling, in dense microparticles of irregular shape. The same bioactive glass powder has 
been used previously in several studies combined with biopolymers, for example to prepare bioactive glass-soy protein composites (Silva et al., 2014).

\subsubsection{Zeta potential measurements}

$\mathrm{A} 2 \mathrm{Zn} 5, \mathrm{~A} 2 \mathrm{Sr} 5$ and $45 \mathrm{~S} 5$ bioactive glass particles were suspended in Phosphate Buffered Saline (PBS, prepared in lab) and distilled $\mathrm{H}_{2} \mathrm{O}$ at a concentration $1 \mathrm{mg} / \mathrm{ml}$, for zeta potential measurements. Zeta potential was measured using a Zetasizer Nano Series (Malvern Instruments, Hoeilaart, Belgium). The microparticle suspensions were transferred into DTS 1060 disposable folded capillary cells. Measurements were carried out at a temperature of $25^{\circ} \mathrm{C}$. Because of possible reaction of bioactive glass with dispersant agent $\left(\mathrm{H}_{2} \mathrm{O}, \mathrm{PBS}\right)$ for each as prepared suspension the $\mathrm{pH}$ was also measured due to its impact on the zeta potential. For bioactive glass-water suspensions, $\mathrm{pH}$ was adjusted to $\mathrm{pH} 7.5$ with $1 \mathrm{M} \mathrm{HCl}$.

The potential was determined five times (each measurement being the average of 100 runs) and the mean values and standard deviations were calculated (see table). The instrument automatically calculates zeta potential according to Smoluchowski's equation.

\subsubsection{Microparticle size distribution measurements}

Microparticle size distributions were measured by laser diffraction (Mastersizer-S long bench, Malvern Instruments, Malvern, UK), using the wet dispersion technique. The powder (about $100 \mathrm{mg})$ was dispersed in $10 \mathrm{ml}$ of a $0.1 \%(\mathrm{~m} / \mathrm{v})$ aqueous polysorbate 80 solution. The resulting suspension was added to the MS1 Small Volume Dispersion unit (Malvern Instruments, Malvern, UK) in order to obtain an obscuration of the laser beam of approximately $20 \%$. The microparticle size distribution was measured using the following parameters: $300 \mathrm{RF}$ lens, $2.4 \mathrm{~mm}$ active beam length, $1500 \mathrm{rpm}$ stirrer speed, 6000 scans, polydisperse analysis model. 


\subsection{Production of hydrogel-bioactive glass composites, rheometry and ion release studies} $\underline{\text { using ICP-OES }}$

Briefly, $1 \mathrm{ml}$ pre-autoclaved $\left(121^{\circ} \mathrm{C}\right.$ for 15 minutes) aqueous $0.875 \%$ (w/v) GG solution was mixed with $200 \mathrm{mg}$ pre-autoclaved bioactive glass particles at room temperature and shaken vigorously to yield $20 \%$ (w/v) GG-bioactive glass composites. To make bioactive glass-free composites as control samples, $800 \mu \mathrm{l} \mathrm{GG}$ solution and $200 \mu \mathrm{l}$ pre-sterilized $0.15 \%(\mathrm{w} / \mathrm{v})$ $\mathrm{CaCl}_{2}$ solution were heated to $70^{\circ} \mathrm{C}$, mixed and allowed to cool and set at room temperature. Gelation speed was investigated by performing rheometrical measurements with an AR1000N Rheometer (TA Instruments). All experiments were performed at $37^{\circ} \mathrm{C}$ at strain $1 \%$ and frequency $1 \mathrm{~Hz}$ using a plate-cone setup with a stainless steel plate and an acrylic cone of 4 cm diameter.

$\underline{\text { To study release of ions from composites, composites of volume } 1 \mathrm{ml} \text { were submerged in } 1 \mathrm{ml}}$ $\underline{\mathrm{ddH}}_{2} \mathrm{O}$ water for $24 \mathrm{~h}$. The water was retained and analyzed using ICP-OES as described previously (Douglas et al., 2012). Samples were directly diluted 1:10 with $0.14 \mathrm{M} \mathrm{HNO}_{3}$ prepared after properly diluting $14 \mathrm{M} \mathrm{HNO}_{3}$ (purchased from Fisher Chemicals, UK, and further purified by sub-boiling distillation in a PFA system) with ultrapure water obtained from an Element Milli-Q water purification system (Merck Millipore, USA). External calibration was performed by measuring multi-element standards of $\mathrm{Ca}, \mathrm{Na}, \mathrm{Zn}, \mathrm{Sr}$ and $\mathrm{P}$ at different concentration levels $\left(0,0.05,0.1,0.5,1,2.5\right.$ and $\left.10 \mathrm{mg} \mathrm{L}^{-1}\right)$, prepared by properly diluting the corresponding single element standard solutions (of $1 \mathrm{~g} \mathrm{~L}^{-1}$ ) with $0.14 \mathrm{M} \mathrm{HNO}_{3}$. $\underline{Y}$ was added in all samples and calibration standards in a concentration of $1 \mathrm{mg} \mathrm{L}^{-1}$ to be used as internal standard to correct for matrix effects and/or possible instrument instability. Elemental quantification measurements were performed in a Spectro Arcos ICP-OES instrument. 3 replicates were performed per sample. Method limits of detection were 
calculated as 3 times the standard deviation of the blanks $(n=20)$ divided by the slope of the $\underline{\text { calibration curve and multiplied by the sample dilution factor (10). }}$

\subsection{Three-dimensional X-ray imaging}

Image acquisition was performed with a laboratory x-ray source at the Detector Lab of the Institute for Photon Science and Synchrotron Radiation at the Karlsruhe Institute of Technology, Karlsruhe, Germany. For x-ray tomography acquisitions, an X-ray tube (Viscom X9160-D ED) was set to $60 \mathrm{kV}$ voltage and $120 \mu \mathrm{A}$ current. For detection, a Dexela 1207 with a $150 \mu \mathrm{m}$ CsI CMOS sensor with active pixel size of $74.8 \mu \mathrm{m}$ was used.

To ensure focal spot limited spatial resolution, the source sample distance and source detector distance were adjusted to $3.5 \mathrm{~cm}$ and $70.0 \mathrm{~cm}$ respectively with a total magnification of $20 \mathrm{x}$ resulting in a pixel size of $3.7 \mu \mathrm{m}$ and a field of view of $3.2 \times 5.7 \mathrm{~mm}^{2}$.

For each measurement, a series of 1200 projection images were taken over a $360^{\circ}$ angular range with an exposure time of $4 \mathrm{~s}$.

GG hydrogel-bioactive glass composites containing A2, A2Sr, A2Zn and 45S5 particles were placed in plastic Eppendorf tubes and visualized by means of x-ray $\mu \mathrm{CT}$.

The 3-D volumes were reconstructed with Octopus software. To quantitatively study bioactive glass agglomerates, the Otsu thresholding method was used with subsequent labelling of connected components in a $3 \mathrm{D}$ volume performed with the morphology module of open source Python library (SciPy) (Jones et al., 2001). Rendering and visualization of segmented bioglass agglomerations in 3D was performed by means of Avizo 8.1 software.

\subsection{Antibacterial testing}

To evaluate antibacterial properties, composites of volume $1 \mathrm{ml}$ were submerged with a silicone disc in $1 \mathrm{ml}$ containing $10^{4} \mathrm{CFU}$ Methicillin-resistant Staphylococcus aureus 
(MRSA) Mu50 in Müller-Hinton broth. The disc served as a substrate for MRSA attachment and growth. After $24 \mathrm{~h}$ incubation at $37^{\circ} \mathrm{C}$, samples were removed, medium was removed and discs were washed with physiological saline to remove non-adhered bacteria. Discs were collected and the number of CFU per silicone discs was determined by plating. Silicone discs without added composites served as a control. For all sample groups, $n=3$. Statistical analysis was performed using a Kruskall-Wallis test and SPSS software. A value of $p \leq 0.05$ was considered significant.

\subsection{Characterization of osteoblast-like cell attachment and growth}

\subsubsection{Cell culture on GG-bioactive glass composites}

Hydrogel composites were cast under sterile conditions in wells of 12-well cell culture plates (TPP, Switzerland), $1 \mathrm{ml}$ per well. $\underline{\text { Six }}-\mathrm{mm}$ discs were cut out using a sterile hole punch and were used for cell culture experiments. For cell adhesion and growth analysis, human osteoblast-like MG-63 cells (European Collection of Cell Cultures, Salisbury, UK; Cat. No. 86051601) were used. These cells are considered as a suitable model for studies on cell $\underline{\text { adhesion and proliferation and have been widely used for testing biocompatibility of various }}$ biomaterials (Douglas et al., 2014b, Jirka et al., 2013, Vandrovcova et al., 2014). Each GGbioactive glass composite was placed in a well of a 24-well plate and a suspension of 100000 cells in $1.5 \mathrm{ml}$ cell culture medium, i.e. GlutaMax High Glucose DMEM containing 10\% fetal bovine serum, $0.1 \mathrm{mM}$ Sodium Pyruvate and 1\% Penicilin-Streptomycin, (all Gibco, Invitrogen), was added.

\subsubsection{Cell visualization}

A LIVE/DEAD staining (Calcein AM/propidium iodide, Life Technologies) was performed to evaluate cell adhesion and growth. After rinsing with PBS, the supernatant was replaced by 1 ml PBS solution supplemented with $2 \mu \mathrm{l}(1 \mathrm{mg} / \mathrm{ml})$ calcein AM and $2 \mu \mathrm{l}(1 \mathrm{mg} / \mathrm{ml})$ propidium 
iodide. Cultures were incubated for 30 minutes at room temperature, washed twice with PBS solution and evaluated by fluorescence microscopy (IX 51 epifluorescence microscope equipped with a DP 70 digital camera; both manufactured by Olympus, Japan). Evaluations were performed on day 3 and 7 post-seeding.

\subsubsection{Metabolic test}

Metabolic activity of the cells was evaluated to estimate the growth (number) of the cells on day 7 after seeding. Triplicates of samples were analyzed. The samples were replaced into fresh wells in 24-well plate and washed with PBS. The composite discs were then incubated in resazurin solution (Alamar blue, Sigma, $40 \mu \mathrm{M}$ work solution) diluted in cell culture medium without phenol red (DMEM with low glucose, without phenol red; Sigma, USA, Cat. No. D2902). After 4 hour incubation in cell culture incubator, the composites were placed back into their cell culture medium. Resazurin fluorescence was measured at $590 \mathrm{~nm}$ with excitation at $530 \mathrm{~nm}$.

\subsubsection{Testing of eluates from composites}

To produce eluates, composites of volume $1 \mathrm{ml}$ were dissected into 4 equal parts. Each part was incubated in $5 \mathrm{ml}$ of cell culture medium at $37{ }^{\circ} \mathrm{C}$ for $48 \mathrm{~h}$. Eluates were diluted in cell culture medium by factors of 1 (undiluted), 2, 4, and 8. MG-63 cells (10000 per well of a 96well plate) were subsequently incubated in eluate at the aforementioned dilutions for $72 \mathrm{~h}$. Afterwards, the eluate was replaced by $0.2 \mathrm{ml}$ resazurin work solution and the metabolic test was followed as described above. Triplicate measurements were performed. The viability was calculated as a percentage of control cultures incubated with cell culture medium without eluate.

\subsubsection{Statistical Analysis}

The quantitative results were presented as the mean $\pm \mathrm{SD}$ (standard deviation). The statistical analyses were performed using SigmaStat (Jandel Corporation, San Jose, CA USA). Multiple 
comparison procedures were carried out by one way ANOVA. The multiple comparisons were counted by the All Pairwise Multiple Comparison Procedure (Bonferroni t-test); multiple comparisons versus control were counted by the Dunnett test. A value of $p \leq 0.05$ was considered significant.

\subsection{Mineralization studies in $S B F$}

\subsubsection{SBF production and sample incubation}

The mineralization process of hydrogel-bioactive glass composites was performed by incubation in simulated body fluid (SBF) prepared according to Kokubo (Kokubo et al., 1990). The composites were immersed in SBF solution and incubated at $37^{\circ} \mathrm{C}$ in separate containers for 28 days. The ratio of the composite's weight $(\mathrm{g})$ and solution's volume $(\mathrm{ml})$ was close $1 / 100$. Afterwards the composites were taken out of SBF, frozen at $-24{ }^{\circ} \mathrm{C}$ and subsequently subjected to a lyophilization process in order to obtain dry mass. Freeze-drying was performed using Labconco FreeZone 61 for 48 hours.

\subsubsection{Physicochemical and morphological characterization of freeze-dried samples post- incubation: FTIR, SEM, ICP-OES}

Prior to FTIR, SEM and ICP-OES analysis, samples were freeze-dried.

Before and after mineralization experiments and subsequent lyophilization, the structure of the hydrogels was examined using FTIR. Spectra were recorded with a Bruker Company Vertex 70v spectrometer using the $\mathrm{KBr}$ technique. Spectra were collected in the range 4000 $\underline{400} \mathrm{~cm}^{-1}$ and 128 scans were accumulated at $4 \mathrm{~cm}^{-1}$ resolution.

Morphology and elemental analysis of all freeze-dried samples before and after mineralization in SBF were determined using SEM (Nova NanoSEM 200 FEI Europe Company, USA, accelerating voltage $15 \mathrm{kV}$ ) coupled with an energy dispersion X-ray (EDX) analyzer. The 
EDX spectra were collected at the point indicated by arrow in SEM image. Materials were analyzed after coating with a thin conductive carbon layer.

Elemental composition of samples was determined using ICP-OES as described previously (Douglas et al., 2012). The ICP-OES technique, with detection limit between $1 \mu \mathrm{g} / \mathrm{dm}^{3}$ and $\underline{1000 \mathrm{~g} / \mathrm{dm}^{3} \text {, was also used to investigate the changes in ion concentration in the SBF after } 14}$ and 28 days of composite incubation.

\section{Results}

3.1 Bioactive glass microparticle characterization, formation of hydrogel-bioactive glass composites and ion release from composites

Laser diffraction analysis results are shown in Figure S1a. A2, A2Zn and A2Sr preparations displayed similar size distributions, with $\mathrm{D}[\mathrm{v}, 0.5]$ values of $17.3,15.5$ and $28.9 \mu \mathrm{m}$, respectively. $\mathrm{D}[\mathrm{v}, 0.5]$ and $\mathrm{D}[\mathrm{v}, 0.9]$ defines the diameter (based on the volume distribution of the particles) at which 50 and $90 \%$ of the particles are smaller than this diameter. Microparticles in the $45 \mathrm{~S} 5$ preparation were markedly smaller, $\mathrm{D}[\mathrm{v}, 0.5]$ and $\mathrm{D}[\mathrm{v}, 0.9]$ values of 2.9 and $6.2 \mu \mathrm{m}$, respectively.

Sterilization by autoclaving had no effect on laser diffraction results (data not shown). Zeta potential measurements are displayed in Table 2. In $d_{d H_{2}} \mathrm{O}$, the strongest alkalization was observed for A2. A2 showed the most neutral zeta potential in $\mathrm{ddH}_{2} \mathrm{O}$, while values for $\mathrm{A} 2 \mathrm{Zn}$ and $\mathrm{A} 2 \mathrm{Sr}$ were more negative by approximately $11 \mathrm{mV}$. The value for $45 \mathrm{~S} 5 \mathrm{was}$ more negative still, approximately $43 \mathrm{mV}$ more negative than for $\mathrm{A} 2$. In $\mathrm{ddH}_{2} \mathrm{O}$ with $\mathrm{pH}$ fixed at 7.5, the most negative zeta potential was exhibited 45S5 (approximately $-23 \mathrm{mV}$ ) followed by A2 (approximately $-8 \mathrm{mV}$ ). A2Zn was marginally more neutral, while A2Sr was markedly more neutral (approximately $-2 \mathrm{mV}$ ). In PBS, alkalization was less extreme than in $\mathrm{ddH}_{2} \mathrm{O}$. 
The strongest alkalization was observed for A2. Zeta potential values between -17 and -19 $\mathrm{mV}$ for $\mathrm{A} 2$ and $\mathrm{A} 2 \mathrm{Sr} 5$, while values for $\mathrm{A} 2 \mathrm{Zn} 5$ were more negative (approximately $-25 \mathrm{mV}$ ) and values for 45S5 were more negative still (approximately $-29 \mathrm{mV}$ ).

Results of rheometrical analysis are displayed in Figure S1b. In all cases, gelation appeared to have reached a plateau value after 20 minutes. Composites containing 45S5 exhibited markedly lower storage modulus values, suggesting lower stiffness.

ICP-OES release of ions after $24 \mathrm{~h}$ (Table 3) revealed that the concentration of $\mathrm{Zn}$ released from composites containing A2Zn5 was $0.16 \pm 0.18 \mathrm{mg} \mathrm{dm}^{-3}$. Sr release from composites containing A2Sr5 was considerably higher (concentration $34.04 \pm 10.46 \mathrm{mg} \mathrm{dm}^{-3}$ ). All composites released $\mathrm{Ca}$. Release of $\mathrm{P}$ was negligible from all composites except those containing 45S5. Release of $\mathrm{Na}$ from composites containing 45S5 was two orders of magnitude higher than that from other composites.

\section{$3.2 X$-ray $\mu C T$ examination}

Transversal sections of hydrogel-bioactive glass composites at two different heights are shown in Figure 1a. It can be seen that the distribution of bioactive glass in the composite containing 45S5 was significantly less homogeneous. The most homogeneous distribution of visible microparticles/microparticle aggregates was observed in the composite containing A2Zn. This was confirmed by imaging of 3D composites distribution, the results of which are shown in Figure $1 b$.

Results of the analysis of the size distribution of the bioactive glass microparticles and microparticle aggregates in composites containing A2, A2Zn, A2Sr and 45S5 are presented in Figures 2, S2, S3, S4 and S5, respectively. A significantly lower number of microparticles/microparticle aggregates was observed in composites containing 45S5 (Figure 2a). Furthermore, the percentage of all microparticles/microparticle aggregates in the smallest 
size range (320-1000 $\mu^{3}$ ) was the lowest. Regarding the detailed size distribution of microparticles/microparticle aggregates (Figures S2, S3, S4, S5), in region I, encompassing microparticle/microparticle aggregate volumes in the range $0-10^{4} \mu \mathrm{m}^{3}$, the highest number of microparticles/microparticle aggregates was observed for the composite containing A2Sr (approximately 110000). Values for composites containing A2 and A2Zn were markedly lower (approximately 50000), while the value for the composite containing 45S5 was markedly lower still (approximately 25000). In region II, encompassing microparticle/microparticle aggregate volumes in the range $10^{4}-10^{5} \mu \mathrm{m}^{3}$, the highest values were observed for the composite containing A2Sr, approximately twice as high as the values for composites containing A2 and A2Zn. The values for the composite containing 45S5 were approximately one order of magnitude lower. The same trend was observed in regions III $\left(10^{5}-10^{6} \mu \mathrm{m}^{3}\right)$ and $\operatorname{IV}\left(10^{6}-10^{7} \mu \mathrm{m}^{3}\right)$.

\subsection{Cell biological characterization with MG-63 osteoblast-like cells}

Fluorescence microscopy images of MG-63 osteoblast-like cells cultured directly on hydrogel-bioactive glass composites and in their eluates are presented in Figure 3a. On composites containing A2, A2Zn and A2Sr, cells remained viable after 3 days, formed viable clusters after 7 days, and in the case of composites containing A2, cell layers were formed. However, no viable cells were observed on composites containing $45 \mathrm{~S} 5$ after 3 days or 7 days. Cells proliferating on the bottom of the same wells together with composites containing A2, A2Zn and A2Sr formed layers of viable cells with no dead cells after 7 days. However, no viable cells and some dead cells were observed in cells cultured together with composites containing 45S5. It was noted that cell culture medium in the presence of composites containing 45S5 was noticeably more purple-colored, suggesting greater alkalization of the medium. 
Cell numbers on composites assessed by metabolic test are displayed in Figure $3 b$. Cell numbers were significantly higher on composites containing $\mathrm{A} 2, \mathrm{~A} 2 \mathrm{Zn}$ and $\mathrm{A} 2 \mathrm{Sr}$ than on those containing 45S5. Furthermore, values for composites A2Zn were significantly higher than those for composites containing A2Sr.

Cell numbers after cultivation in eluates from composites are shown in Figure 3c. Cell proliferation in undiluted eluates was significantly lower, especially for composites containing A2 and 45S5. Values for eluates diluted by a factor of 2 were closer to control values, but still significantly worse for all composites except those containing A2Sr. Cell numbers were not lower than controls when eluates were diluted by factors of 4 or 8 .

\subsection{Antibacterial testing}

The results of antibacterial testing are displayed in Figure 3d. All composites containing bioactive glass showed significantly greater antibacterial activity than bioactive glass-free GG hydrogel controls. The values for composites containing 45S5 were markedly lower than those for the composites containing A2, A2Zn and A2Sr.

\subsection{Mineralization of composites in SBF}

FTIR spectra of hydrogel-bioglass composites before and after 28 days of incubation in SBF are shown in Figure 4. Incubation in SBF resulted in some changes. The bands at 565 and 605 $\mathrm{cm}^{-1}$, corresponding to $v^{4}$ antisymmetric bending of $\mathrm{PO}_{4}{ }^{3-}$ groups became more visible, and the band in the range of $1055-1090 \mathrm{~cm}^{-1}$, corresponding to $v^{4}$ antisymmetric stretching of $\mathrm{PO}_{4}{ }^{3-}$ groups became more intense and narrower (Koutsopoulos, 2002). Furthermore, the increase in intensity of the band at about $870 \mathrm{~cm}^{-1}$, which could be connected with superimposed symmetric stretching mode of the $\mathrm{P}-\mathrm{O}(\mathrm{H})$ bond of the $\mathrm{HPO}_{4}{ }^{2-}$ group and $\mathrm{C}-\mathrm{O}$ vibrations in $\mathrm{CO}_{3}{ }^{2-}$ groups appearing in the structure of calcium phosphate, was observed 
(Koutsopoulos, 2002, Rosseeva et al., 2008). Additionally, a new shoulder at $1220 \mathrm{~cm}^{-1}$ and new band of low intensity at $800 \mathrm{~cm}^{-1}$ appeared, which may be due to silica groups in the $\mathrm{CaP} /$ silica gel layer). The appearance of the aforementioned bands points to the formation of carbonated calcium phosphate $(\mathrm{CaP})$ in the composites upon immersion in SBF. Further indirect evidence is provided by the disappearance or attenuation of bands characteristic for GG at $700 \mathrm{~cm}^{-1}$ and $1430 \mathrm{~cm}^{-1}$

SEM images and EDX spectra of hydrogel-bioactive glass composites before and after 28-day incubation in SBF are shown in Figure 5. In the case of pure GG, no visible morphological changes after immersion in SBF were observed. Elemental analysis revealed the presence of $\mathrm{Na}$ and $\mathrm{Cl}$ on the surface of material. Composites showed morphological changes characteristic for precipitation of calcium phosphate, namely the appearance of roughly spherical, "cauliflower-like" deposits rich in $\mathrm{P}$ and $\mathrm{Ca}$.

Results of elemental analysis by ICP-OES after incubation of hydrogel-bioactive glass composites for 28 days in SBF are shown in Table 4. As expected, no Ca or P was detected in GG controls without bioactive glass. Composites containing A2, A2Zn and A2Sr contained similar masses of $\mathrm{Ca}$ and $\mathrm{P}$. In contrast, the masses of $\mathrm{Ca}$ and $\mathrm{P}$ in composites containing 45S5 were markedly lower. By comparing the molar amounts of elements present after incubation in SBF with the theoretical molar amounts present before incubation in SBF, it can be seen that the $\%$ molar increase in Ca was highest for composites containing 45S5, probably due to the much greater alkalization which favors HA crystallization. Composites containing A2Zn exhibited markedly higher \% molar increases in $\mathrm{Ca}$ and $\mathrm{P}$ than composites containing A2 and A2Sr, but not $45 \mathrm{~S} 5$. Approximately $48 \%$ and $80 \%$ of initial molar amounts of $\mathrm{Zn}$ and $\mathrm{Sr}$, respectively, were lost due to incubation.

$\underline{\text { Ion concentration in SBF after immersion of hydrogel-bioactive glass composites are }}$ presented in Table 5. After 14 days of incubation, hydrogel containing A2, A2Zn and A2Sr 
glasses showed much higher concentration of $\mathrm{Ca}$ in $\mathrm{SBF}$, compared to composites containing 45S5. In all cases, decreases in Ca concentration were observed after 28 days. This correlates $\underline{\text { with the gradual reduction of } \mathrm{P} \text { concentration with increasing incubation time, indicating } \mathrm{CaP}}$ formation. ICP-OES analysis of SBF showed small changes in $\mathrm{Na}$ concentration for composites containing A2, A2Zn5 and A2Sr5, while composites containing 45S5 revealed significant solubility of $\mathrm{Na}^{+}$ions. Concentrations of $\mathrm{Sr}$ and $\mathrm{Zn}$ in SBF determined by ICPOES analysis (Table 5) confirmed the results of elemental composition of composites (Table 4), indicating lower $\mathrm{Zn}$ ion release compared to $\mathrm{Sr}$, which was also indicated during composite incubation in $\mathrm{ddH}_{2} \mathrm{O}$ for $24 \mathrm{~h}$ (Table 3).

\section{Discussion}

As stated in the introduction, it was hypothesized that the composition of the bioactive glass preparation would influence: (i) the speed of gelation of the GG hydrogel to form the hydrogel-bioactive glass composite and the viscoelastic properties of the composite; (ii) the homogeneity of the distribution of the bioactive glass within the composite; (iii) the composites' antibacterial activity; (iv) the adhesion and proliferation of osteoblast-like cells seeded on the composite and (v) the extent of mineral formation upon incubation of the composites in simulated body fluid (SBF).

Composites containing 45S5 were mechanically weaker (Figure S1b). This can be attributed to lower $\mathrm{Ca}^{2+}$ ion release from the preparation, which would result in lower ionic crosslinking of GG. 45S5 is melt-derived, while A2, A2Zn and A2Sr are all sol-gel derived. It is well known that, in general, sol-gel derived bioactive glasses release more ions than melt-derived bioactive glasses. Additionally 45S5 bioactive glass releases also $\mathrm{Na}^{+}$ions which do not 
crosslink as strongly as divalent ions (Morris et al., 2012). Furthermore, the distribution of the 45S5 preparation was markedly less homogeneous. This could be seen visually using X-ray $\mu \mathrm{CT}$ imaging (Figure 1). Furthermore, analysis of bioactive glass microparticles/microparticle aggregates revealed a lower total number of microparticles/aggregates (Figure 2a) and a lower percentage of microparticles/microparticle aggregates in the lowest size category (Figure 2b), which indicate a larger degree of aggregation. It is noteworthy that the 45S5 preparation exhibited the lowest particle size (Figure 1a) but the least homogeneous distribution (Figure 1). This can be assigned to a lower stability and tendency for aggregation of small particles. More neutral zeta potential is certainly not the cause, since the $45 \mathrm{~S} 5$ preparation displayed markedly more negative values (Table 2).

In this study, bioactive glass microparticles/microparticle aggregates of volumes as low as $320 \mu^{3}$ could be detected and quantified (Figure 2b). This volume corresponds to an equivalent microparticle diameter of $8.5 \mu \mathrm{m}$ (assuming a spherical microparticle shape). This is approximately one order of magnitude higher than the resolution obtained in our previous work on synchrotron X-ray $\mu \mathrm{CT}$ analysis of microparticles (Gorodzha et al., 2016). Considering the microparticle diameters calculated by laser diffraction (Figure S1a), it appears that a high proportion of individual bioactive glass microparticles can be detected by the $\mathrm{X}$-ray $\mu \mathrm{CT}$ technique applied in this study. It is known that aggregation of inorganic particles in hydrogels and inhomogeneous distribution are common occurrences (Leeuwenburgh et al., 2010, Leeuwenburgh et al., 2007). The high-resolution technique presented in this study offers the possibility of semi-quantitative or even quantitative evaluation of microparticle dispersion and aggregation in hydrogel biomaterials. This should be useful for evaluating strategies to reduce microparticle aggregation and improve dispersion. 
The poorer cell proliferation on composites containing 45S5 and in the eluates from these composites might be ascribed to increased alkalization of the medium due to $\mathrm{Na}^{+}$ions release as was confirmed by ICP-OES analysis of SBF (Figure 3a, $3 \mathrm{~b}$ and $3 \mathrm{c}$, Table 5). Another possible explanation is a relatively low stiffness of these materials. It is known that the adhesion and spreading of cells on soft and deformable materials is limited or even disabled, because these materials cannot resist the tractional forces generated by cells (for a review, see (Bacakova et al., 2011)). Similarly, the osteogenic differentiation of human umbilical cord stem cells was lower on polyacrylamide gels of a lower stiffness (Witkowska-Zimny et al., 2012). In addition, the composites containing 45S5 had a markedly more negative zeta potential. In our earlier studies, negative zeta potential was associated with a lower proliferation of human osteoblast-like MG-63 and Saos-2 cells (Jirka et al., 2013, Vandrovcova et al., 2014).

It is noteworthy that cells seeded on composites containing A2Zn and A2Sr did not proliferate worse than those seeded on composites containing A2, which did not contain any Zn or Sr. Hence, incorporation of $\mathrm{Zn}$ or $\mathrm{Sr}$ in bioactive glass does not adversely affect cytocompatibility. Cells cultured directly on composites containing A2, A2Zn and A2Sr displayed a round, spherical morphology after 1 day, but a more spread morphology after 7 days, suggesting better adhesion. It is possible that this improved morphology is due to proteins secreted by the cells in the course of 7 days which adsorbed to the composite surface.

The antibacterial effect of composites containing A2 observed in this study (Figure 3d) is consistent with results reported in previous work (Douglas et al., 2014b). Composites containing A2Zn were not more antibacterial than those containing A2 or A2Sr, despite the well-known antibacterial effect of $\mathrm{Zn}$. It may be that insufficient amounts of $\mathrm{Zn}$ were released 
from composites. ICP-OES analysis of SBF (Table 5) confirmed low solubility of Zn ions from this material even in long-term incubation (up to 28 days). Furthermore, ICP-OES analysis also revealed low $\mathrm{Zn}$ release into $\mathrm{ddH}_{2} \mathrm{O}$ (Table 3). GG has been reported to have a higher affinity for $\mathrm{Zn}^{2+}$ than $\mathrm{Ca}^{2+}$ (Verma et al., 2012), hence $\mathrm{Zn}^{2+}$ release may have been impeded by the GG hydrogel network. The higher antibacterial activity of composites containing $45 \mathrm{~S} 5$ might be ascribed to an increase in $\mathrm{pH}$ of the bacterial culture medium; however, this may not be the only factor. Indeed, increases in $\mathrm{pH}$, high ion release (mainly $\underline{\mathrm{Na}^{+} \text {, which is one of the main component in } 45 \mathrm{~S} 5 \mathrm{glass} ; \mathrm{Na}^{+} \text {release in } \mathrm{ddH}_{2} \mathrm{O} \text { after } 24 \mathrm{~h} \text { was }}$ approximately two orders of magnitude higher from composites containing 45S5 than from other composites (Table 3)), ionic strength and bioactive glass debris production have all been proposed to contribute to antibacterial effect of bioactive glasses in solution (Allan et al., 2001, Gubler et al., 2008, Hu et al., 2009, Misra et al., 2010, Zehnder et al., 2006, Stoor et al., 1998). The antibacterial effect of 45S5 in this study is consistent with the results obtained in some studies (Hu et al., 2009, Misra et al., 2010, Rivadeneira et al., 2013), although it should be noted that little or no antibacterial effect was demonstrated in other studies (Bellantone et al., 2002, Gorriti et al., 2009, Xie et al., 2008). Further work should involve bacteria different from Staphylococcus aureus.

Formation of CDHA in composites containing bioactive glasses after incubation in SBF was confirmed directly by FTIR (Figure 4) and SEM/EDX (Figure 5) analysis, and indirectly by the increase in $\mathrm{Ca}$ and $\mathrm{P}$ content measured using ICP-OES (Table 3). The reasons for the higher relative increases in $\mathrm{Ca}$ and $\mathrm{P}$ in composites containing $\mathrm{A} 2 \mathrm{Zn}$ and 45S5 remain unclear. Nevertheless, it is known that some ceramic materials, e, g. hydroxyapatite and other calcium phosphates, are able to trap actively $\mathrm{Ca}$ ions from the surrounding solutions, e.g. from the cell culture medium, and this depletion of $\mathrm{Ca}$ attenuates the cell growth on these substrates 
(Mestres et al., 2012, Schumacher et al., 2013). X-ray $\mu$ CT examination (Figures 1, 2, S2, S3, S4, S5) did not reveal more homogeneous distribution of bioactive glass in these composites. Nor was a greater number or proportion of small microparticles/aggregates in Regions I and II observed. Hence, it seems unlikely that the differences in amounts of $\mathrm{Ca}$ and $\mathrm{P}$ are due to differences in surface area of bioactive glass available for CDHA deposition. It is conceivable that differences in ion release rates from the different bioactive glass preparations may have played a role.

More $\mathrm{Zn}$ than $\mathrm{Sr}$ remained in composites after incubation in SBF for 28 days (Table $\underline{4}$ ). It is conceivable that $\mathrm{Zn}$ released from bioactive glass may have been incorporated into newly formed CDHA to a greater extent than Sr. Another possibility is that due to the greater extent of mineral formation in composites containing $\mathrm{A} 2 \mathrm{Zn} \underline{5}$, the diffusion of $\mathrm{Zn}$ out of composites may have been impeded to a greater extent. Other factors may be differing affinities of GG for $\mathrm{Zn}$ and Sr. A stronger affinity would lead to more retention within the hydrogel network.

\section{Conclusion}

Novel injectable, self-gelling composites of GG hydrogels containing $20 \%$ bioactive glass were prepared by a simple mixing technique. Gelation occurred within an acceptable time frame for injection (within 20 minutes). Composites containing the standard 45S5 bioactive glass preparation were markedly less stiff. X-ray $\mu \mathrm{CT}$ proved to be a technique capable of detecting microparticles of diameter approximately $8 \mu \mathrm{m}$, i.e. individual microparticles. The size distribution of bioactive glass microparticles and their aggregates, and their distribution in GG hydrogels, was visualized accurately using this high-resolution technique. A2, A2Zn and A2Sr bioactive glass microparticles were more homogeneously dispersed in GG 
hydrogels than those of the standard 45S5 preparation. Composites containing all four bioactive glass preparations exhibited antibacterial activity against MRSA. Composites containing, A2Zn and A2Sr bioactive glass preparations supported the adhesion and growth of osteoblast-like cells and were considerably more cytocompatible than those of the standard 45S5 bioactive glass preparation. All composites underwent mineralization with CDHA upon incubation in SBF. The extent of mineralization appeared to be greatest for composites containing A2Zn and 45S5. The results underline the importance of the choice of bioactive glass when preparing injectable, self-gelling composites.

\section{Acknowledgement}

Timothy E.L. Douglas acknowledges the Research Foundation Flanders (FWO) for support in the framework of a postdoctoral fellowship. Dr. Elias Hamann, Roman Shkarin and Marcus Zuber are thanked for technical assistance during the X-Ray $\mu \mathrm{CT}$ measurements. Andre G. Skirtach thanks BOF (Bijzonder Onzderzoeksfonds) of Ghent University and FWO for support. The Era-Net Rus Plus program is acknowledged for support in the framework of the project "Fabrication and investigation of new hybrid scaffolds with the controlled porous hierarchy for bone tissue engineering” (Federal Target Program \#14.587.21.0013, a unique application number 2015-14-588-0002-5599, project IntelBioComp). Jana Lišková and Lucie

Bačáková acknowledge the Agency for the Czech Republic Health Research, Ministry of Health of the Czech Republic for financial support (grant No. 15-32497A). Katarzyna Cholewa-Kowalska and Michał Dziadek acknowledge National Science Centre, Poland for financial support project no 2014/13/B/ST8/02973.

\section{Conflict of Interest, Ethical Approval, Original Publication and Author Contribution Statements}


The authors have no conflict of interest. No ethical approval was required for this study. No part of this work has been previously published or submitted for publication elsewhere. The authors made the following contributions to the paper:

Timothy E.L. Douglas conceived, designed, planned and coordinated the study, performed rheometrical measurements (Figure S1b), interpreted the data and wrote the vast majority of the manuscript, under the guidance of Andre G. Skirtach.

Michał Dziadek and Katarzyna Cholewa-Kowalska synthesized the bioactive glass preparations $\mathrm{A} 2, \mathrm{~A} 2 \mathrm{Zn} \underline{5}$ and $\mathrm{A} 2 \mathrm{Sr} \underline{5}$ (Table 1), performed zeta-potential measurements (Table 2), incubation studies in SBF and subsequent FTIR and SEM analysis (Figures 4, 5), and ICPOES studies of SBF after composite incubation (Table 5).

Svetlana Gorodzha Venera Weinhardt, Tilo Baumbach, Maria A. Surmeneva and Roman A. Surmenev performed X-ray $\mu \mathrm{CT}$ measurements and interpreted the data (Figures 1, 2, S2, S3, S4, S5).

Jana Lišková and Lucie Bačáková performed cell biological characterization and interpretation of these results in context with the material properties (Figure 3a, b, c).

Gilles Brackman and Tom Coenye performed antibacterial testing (Figure 3d).

Chris Vervaet and Valérie Vanhoorne performed laser diffraction measurements (Figure S1a). Lieve Balcaen, Maria del Rosario Florez Garcia and Frank Vanhaecke performed ICP-OES analysis (Tables $3 \underline{\&} 4)$.

Aldo R. Boccaccini provided 45S5 bioactive glass and contributed substantially to data interpretation.

All authors contributed to writing parts of the paper and provided corrections as appropriate for preparation of the final version of the manuscript. 


\begin{tabular}{|c|c|c|c|}
\hline \multirow{2}{*}{ Bioactive glass type } & \multirow[t]{2}{*}{$\mathrm{pH}$} & \multicolumn{2}{|c|}{ Zeta potential $(\mathrm{mV})$} \\
\hline & & mean & s.d. \\
\hline$\underline{\mathrm{A} 2 / \mathrm{H}_{2}} \underline{\mathrm{O}}$ & $\underline{11,6}$ & -1.68 & $\underline{0.40}$ \\
\hline$\underline{\mathrm{A} 2 / \mathrm{H}_{2}} \underline{\mathrm{O}}$ & 7,5 stabilized $\mathrm{HCl}$ & $\underline{-8.08}$ & $\underline{0.43}$ \\
\hline $\mathrm{A} 2 / \mathrm{PBS}$ & 9,5 & -17.32 & $\underline{0.86}$ \\
\hline$\underline{\mathrm{A} 2 \mathrm{Zn} 5 / \mathrm{H}_{2}} \underline{\mathrm{O}}$ & $\underline{10.5}$ & $\underline{-13.16}$ & $\underline{0.77}$ \\
\hline$\underline{\mathrm{A} 2 \mathrm{Zn} 5 / \mathrm{H}_{2}} \underline{\mathrm{O}}$ & 7.5 stabilized $\mathrm{HCl}$ & $\underline{-6.36}$ & $\underline{0.52}$ \\
\hline A2Zn5/PBS & 8.1 & -25.14 & 1.01 \\
\hline$\underline{\mathrm{A} 2 \mathrm{Sr} 5 / \mathrm{H}_{2}} 2 \underline{\mathrm{O}}$ & $\underline{10.6}$ & -13.3 & $\underline{0.69}$ \\
\hline$\underline{\mathrm{A} 2 \mathrm{Sr} 5 / \mathrm{H}_{2}} \underline{\mathrm{O}}$ & 7.5 stabilized $\mathrm{HCl}$ & -2.3 & $\underline{0.69}$ \\
\hline A2Sr5/PBS & 9.5 & -17.5 & $\underline{0.58}$ \\
\hline$\underline{45 \mathrm{~S} 5 / \mathrm{H}_{2}} 2 \underline{\mathrm{O}}$ & 10.2 & -56.4 & $\underline{0.63}$ \\
\hline$\underline{45 \mathrm{~S} 5 / \mathrm{H}_{2}} \underline{\mathrm{O}}$ & 7.5 stabilized $\mathrm{HCl}$ & -23.03 & $\underline{0.75}$ \\
\hline$\underline{45 \mathrm{~S} 5 / \mathrm{PBS}}$ & 9.1 & $\underline{-29.3}$ & 0.7 \\
\hline
\end{tabular}

Table 2. Bioactive glass zeta potential measurements in $\mathrm{ddH}_{2} \underline{\mathrm{O}}, \mathrm{ddH}_{2} \underline{\mathrm{O}}$ with maintenance of $\mathrm{pH}$ at 7.5 by addition of $\mathrm{HCl}$ and PBS. s.d.: standard deviation 


\begin{tabular}{|c|c|c|c|c|c|c|c|c|c|c|}
\hline$\underline{\text { Sample }}$ & \multicolumn{2}{|c|}{$\mathrm{Ca}\left(\mathrm{mg} \mathrm{dm}^{-3}\right)$} & \multicolumn{2}{|c|}{$\mathrm{Na}\left(\mathrm{mg} \mathrm{dm}^{-3}\right)$} & \multicolumn{2}{|c|}{$\mathrm{Zn}\left(\mathrm{mg} \mathrm{dm}^{-3}\right)$} & \multicolumn{2}{|c|}{$\underline{\mathrm{Sr}\left(\mathrm{mg} \mathrm{dm}^{-3}\right)}$} & \multicolumn{2}{|c|}{$\mathrm{P}\left(\mathrm{mg} \mathrm{dm^{-3 } )}\right.$} \\
\hline group & mean & s.d. & mean & s.d. & mean & s.d. & mean & s.d. & mean & s.d. \\
\hline $\mathrm{A} 2$ & 16.72 & 2.80 & 4.30 & 1.66 & n.d. & n.d. & $\underline{0.12}$ & $\underline{0.05}$ & n.d. & n.d. \\
\hline $\mathrm{A} 2 \mathrm{Zn} 5$ & 8.07 & 1.86 & 4.95 & $\underline{1.80}$ & $\underline{0.16}$ & $\underline{0.18}$ & $\underline{0.16}$ & $\underline{0.02}$ & n.d. & n.d. \\
\hline A2Sr5 & $\underline{14.08}$ & 3.88 & 4.07 & 2.80 & n.d. & n.d. & 34.04 & $\underline{10.46}$ & n.d. & n.d. \\
\hline $45 \mathrm{~S} 5$ & $\underline{1.40}$ & 0.25 & 391.45 & 102.56 & n.d. & n.d. & $\underline{0.18}$ & $\underline{0.14}$ & 2.18 & $\underline{0.85}$ \\
\hline Medium & & & & & & & & & & \\
\hline (control) & $\underline{0.014}$ & $\underline{0.001}$ & n.d. & n.d. & n.d. & n.d. & $\underline{0.05}$ & $\underline{0.002}$ & n.d. & n.d. \\
\hline
\end{tabular}

Table 3. ICP-OES determination of elemental release from composites after $24 \mathrm{~h}$ incubation

in release medium. s.d.: standard deviation. n.d. : not detectable (below detection limit).

\begin{tabular}{|c|c|c|c|c|c|c|c|c|}
\hline$\underline{\text { Sample }}$ & \multicolumn{8}{|c|}{ Element detected (all units $\mathrm{mg} \mathrm{g}^{-1}$ sample) } \\
\hline \multirow[t]{2}{*}{ group } & \multicolumn{2}{|c|}{$\underline{\mathrm{Ca}}$} & \multicolumn{2}{|c|}{$\underline{\mathrm{P}}$} & \multicolumn{2}{|c|}{$\underline{\mathrm{Zn}}$} & \multicolumn{2}{|c|}{$\underline{\mathrm{Sr}}$} \\
\hline & mean & s.d. & mean & s.d. & mean & s.d. & mean & s.d. \\
\hline$\underline{\mathrm{GG}}$ & n.d. & n.d. & n.d. & n.d. & n.d. & n.d. & n.d. & n.d. \\
\hline A2 & 185.8 & 8.0 & 50.6 & 1.0 & n.d. & n.d. & n.d. & n.d. \\
\hline$\underline{\mathrm{A} 2 \mathrm{Zn} 5}$ & 198.9 & 7.0 & 55.1 & 2.8 & 5.3 & 0.1 & n.d. & n.d. \\
\hline $\mathrm{A} 2 \mathrm{Sr} 5$ & 172.7 & 3.4 & 49.1 & 1.6 & n.d. & n.d. & 2.6 & $\underline{0.5}$ \\
\hline $45 \mathrm{~S} 5$ & 123.9 & 2.1 & 27.5 & 0.8 & n.d. & n.d. & n.d. & n.d. \\
\hline$\underline{\text { Sample }}$ & \multicolumn{8}{|c|}{ Element detected (all units \% relative to initial elemental content) } \\
\hline \multirow[t]{2}{*}{ group } & \multicolumn{2}{|c|}{$\underline{\mathrm{Ca}}$} & \multicolumn{2}{|c|}{$\underline{\mathrm{P}}$} & \multicolumn{2}{|c|}{$\underline{\mathrm{Zn}}$} & \multicolumn{2}{|c|}{$\underline{\mathrm{Sr}}$} \\
\hline & mean & s.d. & mean & s.d. & mean & s.d. & mean & s.d. \\
\hline GG & n.d. & n.d. & n.d. & n.d. & n.d. & n.d. & n.d. & n.d. \\
\hline
\end{tabular}




\begin{tabular}{||c|c|c|c|c|c|c|c|c|}
\hline$\underline{\mathrm{A} 2}$ & $\underline{269.8}$ & $\underline{11.6}$ & $\underline{427.1}$ & $\underline{8.8}$ & $\underline{\text { n.d. }}$ & $\underline{\text { n.d. }}$ & $\underline{\text { n.d. }}$ & $\underline{\text { n.d. }}$ \\
\hline$\underline{\mathrm{A} 2 \mathrm{Zn} 5}$ & $\underline{324.7}$ & $\underline{11.4}$ & $\underline{474.5}$ & $\underline{24.2}$ & $\underline{51.6}$ & $\underline{0.7}$ & $\underline{\text { n.d. }}$ & $\underline{\text { n.d. }}$ \\
\hline$\underline{\mathrm{A} 2 \mathrm{Sr} 5}$ & $\underline{286.8}$ & $\underline{5.6}$ & $\underline{430.8}$ & $\underline{13.8}$ & $\underline{\text { n.d. }}$ & $\underline{\text { n.d. }}$ & $\underline{19.6}$ & $\underline{3.8}$ \\
\hline$\underline{45 \mathrm{~S} 5}$ & $\underline{354.4}$ & $\underline{5.9}$ & $\underline{457.3}$ & $\underline{13.0}$ & $\underline{\text { n.d. }}$ & $\underline{\text { n.d. }}$ & $\underline{\text { n.d. }}$ & $\underline{\text { n.d. }}$ \\
\hline
\end{tabular}

Table 4. ICP-OES determination of $\mathrm{mg}$ of elements present per $\mathrm{g}$ sample after $28 \mathrm{~d}$ incubation in SBF (top) and molar \% of elements present per g sample after $28 \mathrm{~d}$ incubation in SBF relative to molar \% of sample before incubation (bottom). s.d.: standard deviation. n.d. : not $\underline{\text { detectable (below detection limit). }}$ 


\begin{tabular}{|c|c|c|c|c|c|c|c|}
\hline Sample & Incubation & \multicolumn{6}{|c|}{$\underline{\mathrm{mM} \mathrm{dm}}{ }^{-3}$} \\
\hline \multirow[t]{2}{*}{ group } & \multirow[t]{2}{*}{ time } & \multicolumn{2}{|c|}{$\underline{\mathrm{Ca}}$} & \multicolumn{2}{|c|}{$\mathrm{Na}$} & \multicolumn{2}{|c|}{$\underline{P}$} \\
\hline & & $\underline{\text { mean }}$ & s.d. & mean & s.d. & mean & s.d. \\
\hline$\underline{\text { SBF }}$ & & 2.513 & $\underline{0.014}$ & 142.625 & 0.254 & $\underline{0.320}$ & $\underline{0.002}$ \\
\hline \multirow[t]{2}{*}{$\underline{\mathrm{A} 2}$} & 14 days & $\underline{8.581}$ & $\underline{0.045}$ & $\underline{137.602}$ & 1.452 & $\underline{0.014}$ & $\underline{0.001}$ \\
\hline & 28 days & $\underline{5.415}$ & $\underline{0.088}$ & 131.254 & 1.452 & $\underline{0.006}$ & $\underline{0.001}$ \\
\hline \multirow[t]{2}{*}{ A2Zn5 } & 14 days & 7.448 & $\underline{0.098}$ & 137.289 & 1.245 & $\underline{0.017}$ & $\underline{0.003}$ \\
\hline & 28 days & 5.028 & $\underline{0.014}$ & 133.221 & 1.459 & $\underline{0.006}$ & 0.002 \\
\hline \multirow[t]{2}{*}{$\underline{\mathrm{A} 2 \mathrm{Sr} 5}$} & 14 days & $\underline{8.278}$ & $\underline{0.101}$ & 136.748 & 2.145 & $\underline{0.163}$ & $\underline{0.010}$ \\
\hline & 28 days & 5.347 & $\underline{0.046}$ & 132.842 & $\underline{0.896}$ & $\underline{0.091}$ & 0.011 \\
\hline \multirow[t]{2}{*}{$\underline{45 \mathrm{~S} 5}$} & 14 days & $\underline{4.776}$ & 0.032 & 182.541 & 2.146 & 0.039 & $\underline{0.007}$ \\
\hline & 28 days & 3.330 & $\underline{0.079}$ & 179.302 & 1.002 & $\underline{0.014}$ & $\underline{0.003}$ \\
\hline \multirow{3}{*}{$\begin{array}{l}\text { Sample } \\
\text { group }\end{array}$} & \multirow{3}{*}{$\begin{array}{c}\text { Incubation } \\
\text { time }\end{array}$} & \multicolumn{6}{|c|}{$\mathrm{mM} \mathrm{dm}{ }^{-3}$} \\
\hline & & \multicolumn{2}{|c|}{$\underline{\mathrm{Si}}$} & \multicolumn{2}{|c|}{$\underline{\mathrm{Sr}}$} & \multicolumn{2}{|c|}{$\underline{\mathrm{Zn}}$} \\
\hline & & mean & s.d. & mean & mean & s.d. & mean \\
\hline$\underline{\mathrm{SBF}}$ & & n.d. & n.d. & n.d. & n.d. & n.d. & n.d. \\
\hline \multirow[t]{2}{*}{$\mathrm{A} 2$} & 14 days & 0.258 & 0.021 & n.d. & 0.258 & 0.021 & n.d. \\
\hline & 28 days & 0.717 & $\underline{0.035}$ & n.d. & $\underline{0.717}$ & $\underline{0.035}$ & n.d. \\
\hline \multirow[t]{2}{*}{$\underline{\mathrm{A} 2 \mathrm{Zn} 5}$} & 14 days & $\underline{0.373}$ & $\underline{0.036}$ & n.d. & $\underline{0.373}$ & $\underline{0.036}$ & n.d. \\
\hline & 28 days & $\underline{0.755}$ & $\underline{0.009}$ & n.d. & $\underline{0.755}$ & $\underline{0.009}$ & n.d. \\
\hline \multirow[t]{2}{*}{$\underline{\mathrm{A} 2 \mathrm{Sr} 5}$} & 14 days & $\underline{0.288}$ & $\underline{0.020}$ & $\underline{0.003}$ & $\underline{0.288}$ & $\underline{0.020}$ & $\underline{0.003}$ \\
\hline & 28 days & $\underline{0.794}$ & $\underline{0.025}$ & $\underline{0.009}$ & $\underline{0.794}$ & $\underline{0.025}$ & 0.009 \\
\hline \multirow[t]{2}{*}{$\underline{45 \mathrm{~S} 5}$} & 14 days & $\underline{0.419}$ & $\underline{0.012}$ & n.d. & $\underline{0.419}$ & $\underline{0.012}$ & n.d. \\
\hline & 28 days & $\underline{0.844}$ & 0.022 & n.d. & $\underline{0.844}$ & 0.022 & n.d. \\
\hline
\end{tabular}


Table 5. The changes ion concentrations in SBF during 14- and 28-day incubation of the composites. s.d.: standard deviation. n.d. : not detectable (below detection limit).

1

2

3

4

5

6

7

8

9

10

11

12

13

14

15

16

17

18

19

20

21

22

23

24

25

26

27

28

29

30

31

32

33

34

35

36

37

38

39

40

41

42

43

44

45

46

47

48

49

50

51

52

53

54

55

56

57

58

59

60 


\section{Figures and Figure captions}

Figure 1. X-ray $\mu \mathrm{CT}$-based visualization of hydrogel-bioactive glass composites. a)

Transverse sections through two different heights (close to the top and close to the bottom) for each composite type. b) 3D rendering of composite type. GG hydrogels without bioactive glass served as controls.

Figure 2. X-ray $\mu \mathrm{CT}$-based analysis of sizes of bioactive glass microparticles and microparticle aggregates present in composites. a) Logarithmic histograms displaying size distributions of microparticles/aggregates in composites. b) Pie charts showing percentage of a total number of microparticles/aggregates in each size region.

Figure 3. Cell biological and antibacterial testing of hydrogel-bioactive glass composites. a) columns, from left to right: A2, A2Zn5, A2Sr5, 45S5. Top row: MG-63 cells cultured directly on composites after 3 days. Middle row: cells cultured directly on composites after 7 days. Bottom row: cells cultured on the bottom of the same well with the composite (in eluates) for 7 days. Scale bar $=200 \mu \mathrm{m}$ in all images. b) Proliferation on composites after 7 days. Values are expressed as percentages of control values. ${ }^{*}: \mathrm{p}<0.05$ relative to control $(\mathrm{Ctrl}), \#: \mathrm{p}<$ 0.05 relative to composite containing $45 \mathrm{~S} 5, \S: \mathrm{p}<0.05$ relative to composite containing A2Sr5. c) Proliferation of cells cultured for 7 days in eluates from composites, both undiluted and diluted by factors of 2, 4 and 8 . Values are expressed as percentages of control values. *: $\mathrm{p}<0.05$ relative to control. d) Colony-forming units (CFU) of MRSA cultured in the presence of composites for $24 \mathrm{~h} . *$ : $\mathrm{p}<0.05$ relative to GG hydrogel without bioactive glass (CTRL 
GG);^: $\mathrm{p}<0.05$ relative to A2, A2Zn5 and A2Sr5. Error bars show standard deviation in all sub-diagrams.

Figure 4. FTIR spectra of hydrogel-bioactive glass composites before and after incubation in SBF for 28 days.

Figure 5. SEM images and EDX spectra (collected at the point indicated by arrow) of hydrogel-bioactive glass composites before and after 28-day incubation in SBF

Figure S1. a) Size distributions of bioactive glass microparticles measured by laser diffraction. b) Gelation kinetics of hydrogel-bioactive glass composites measured by rheometry. Error bars indicated standard deviation.

Figure S2. Analysis of microparticle aggregates sizes present in composites containing bioactive glass preparation $\mathrm{A} 2$, based on X-ray $\mu \mathrm{CT}$ data

Figure S3. Analysis of microparticle aggregates sizes present in composites containing bioactive glass preparation $\mathrm{A} 2 \mathrm{Zn}$, based on X-ray $\mu \mathrm{CT}$ data

Figure S4. Analysis of microparticle aggregates sizes present in composites containing bioactive glass preparation $\mathrm{A} 2 \mathrm{Sr}$, based on X-ray $\mu \mathrm{CT}$ data

Figure S5. Analysis of microparticle aggregates sizes present in composites containing bioactive glass preparation $45 \mathrm{~S} 5$, based on X-ray $\mu \mathrm{CT}$ data 


\section{References}

ALLAN, I., NEWMAN, H. \& WILSON, M. (2001) Antibacterial activity of particulate Bioglass (R) against supra- and subgingival bacteria. Biomaterials, 22, 1683-1687.

BACAKOVA, L., FILOVA, E., PARIZEK, M., RUML, T. \& SVORCIK, V. (2011) Modulation of cell adhesion, proliferation and differentiation on materials designed for body implants. Biotechnology Advances, 29, 739-767.

BELLANTONE, M., WILLIAMS, H. D. \& HENCH, L. L. (2002) Broad-spectrum bactericidal activity of Ag2O-doped bioactive glass. Antimicrobial Agents and Chemotherapy, 46, 19401945.

BOANINI, E., TORRICELLI, P., FINI, M., SIMA, F., SERBAN, N., MIHAILESCU, I. N. \& BIGI, A. (2012) Magnesium and strontium doped octacalcium phosphate thin films by matrix assisted pulsed laser evaporation. J Inorg Biochem, 107, 65-72.

DOUGLAS, T., WLODARCZYK, M., PAMULA, E., DECLERCQ, H., DE MULDER, E., BUCKO, M., BALCAEN, L., VANHAECKE, F., CORNELISSEN, R., DUBRUEL, P., JANSEN, J. \& LEEUWENBURGH, S. (2014a) Enzymatic mineralization of gellan gum hydrogel for bone tissue-engineering applications and its enhancement by polydopamine. J Tissue Eng Regen Med, 8, 906-918.

DOUGlas, T. E., MESSERSMITH, P. B., CHASAN, S., MIKOS, A. G., DE MULDER, E. L., DICKSON, G., SCHAUBROECK, D., BALCAEN, L., VANHAECKE, F., DUBRUEL, P., JANSEN, J. A. \& LEEUWENBURGH, S. C. (2012) Enzymatic mineralization of hydrogels for bone tissue engineering by incorporation of alkaline phosphatase. Macromol Biosci, 12, 1077-89.

DOUGLAS, T. E., PIWOWARCZYK, W., PAMUlA, E., LISKOVA, J., SCHAUBROECK, D., LEEUWENBURGH, S. C., BRACKMAN, G., BALCAEN, L., DETSCH, R., DECLERCQ, H., CHOLEWA-KOWALSKA, K., DOKUPIL, A., CUIJPERS, V. M., VANHAECKE, F., CORNELISSEN, R., COENYE, T., BOCCACCINI, A. R. \& DUBRUEL, P. (2014b) Injectable self-gelling composites for bone tissue engineering based on gellan gum hydrogel enriched with different bioglasses. Biomed Mater, 9, 045014.

DOUGLAS, T. E. L., PILARZ, M., LOPEZ-HEREDIA, M., BRACKMAN, G., SCHAUBROECK, D., BALCAEN, L., BLIZNUK, V., DUBRUEL, P., KNABE-DUCHEYNE, C., VANHAECKE, F., COENYE, T. \& PAMULA, E. (2015) Composites of gellan gum hydrogel enzymatically mineralized with calcium-zinc phosphate for bone regeneration with antibacterial activity. $J$ Tiss Eng Regen Med, EPub 15.7.2015.

DZIADEK, M., ZAGRAJCZUK, B., MENASZEK, E., WEGRZYNOWICZ, A., PAWLIK, J. \& CHOLEWA-KOWALSKA, K. (2016) Gel-derived SiO2-CaO-P2O5 bioactive glasses and glass-ceramics modified by SrO addition. Ceramics International, 42, 5842-5857.

GKIONI, K., LEEUWENBURGH, S. C., DOUGLAS, T. E., MIKOS, A. G. \& JANSEN, J. A. (2010) Mineralization of hydrogels for bone regeneration. Tissue Eng Part B Rev, 16, 577-85.

GORODZHA, S., DOUGLAS, T. E., SAMAL, S. K., DETSCH, R., CHOLEWA-KOWALSKA, K., BRAECKMANS, K., BOCCACCINI, A. R., SKIRTACH, A. G., WEINHARDT, V., BAUMBACH, T., SURMENEVA, M. A. \& SURMENEV, R. A. (2016) High-resolution synchrotron X-ray analysis of bioglass-enriched hydrogels. J Biomed Mater Res A, 104, 1194201.

GORRITI, M. F., LOPEZ, J. M. P., BOCCACCINI, A. R., AUDISIO, C. \& GORUSTOVICH, A. A. (2009) In vitro Study of the Antibacterial Activity of Bioactive Glass-ceramic Scaffolds. Advanced Engineering Materials, 11, B67-B70.

GUBLER, M., BRUNNER, T. J., ZEHNDER, M., WALTIMO, T., SENER, B. \& STARK, W. J. (2008) Do bioactive glasses convey a disinfecting mechanism beyond a mere increase in $\mathrm{pH}$ ? International Endodontic Journal, 41, 670-678.

HENCH, L. L. (1998) Bioceramics. Journal of the American Ceramic Society, 81, 1705-1728. 
HOPPE, A., GULDAL, N. S. \& BOCCACCINI, A. R. (2011) A review of the biological response to ionic dissolution products from bioactive glasses and glass-ceramics. Biomaterials, 32, 275774.

HU, S., CHANG, J., LIU, M. Q. \& NING, C. Q. (2009) Study on antibacterial effect of 45S5 Bioglass(A (R)). Journal of Materials Science-Materials in Medicine, 20, 281-286.

HUM, J. \& BOCCACCINI, A. R. (2012) Bioactive glasses as carriers for bioactive molecules and therapeutic drugs: a review. Journal of Materials Science-Materials in Medicine, 23, 23172333.

JIRKA, I., VANDROVCOVA, M., FRANK, O., TOLDE, Z., PLSEK, J., LUXBACHER, T., BACAKOVA, L. \& STARY, V. (2013) On the role of Nb-related sites of an oxidized betaTiNb alloy surface in its interaction with osteoblast-like MG-63 cells. Materials Science \& Engineering C-Materials for Biological Applications, 33, 1636-1645.

JONES, E., OLIPHANT, E. \& P., P. (2001) SciPy:Open Source Scientific Tools for Python.

JONES, J. R. (2013) Review of bioactive glass: From Hench to hybrids. Acta Biomaterialia, 9, 44574486.

KOKUBO, T., ITO, S., HUANG, Z. T., HAYASHI, T., SAKKA, S., KITSUGI, T. \& YAMAMURO, T. (1990) Ca,P-rich layer formed on high-strength bioactive glass-ceramic A-W. J Biomed Mater Res, 24, 331-43.

KOUTSOPOULOS, S. (2002) Synthesis and characterization of hydroxyapatite crystals: A review study on the analytical methods. J Biomed Mater Res 62, 600-612.

LACZKA, M., CHOLEWA-KOWALSKA, K., LACZKA-OSYCZKA, A., TWORZYDLO, M. \& TURYNA, B. (2000) Gel-derived materials of a CaO-P(2)O(5)-SiO(2) system modified by boron, sodium, magnesium, aluminum, and fluorine compounds. J Biomed Mater Res, 52, 601-12.

LEEUWENBURGH, S. C., ANA, I. D. \& JANSEN, J. A. (2010) Sodium citrate as an effective dispersant for the synthesis of inorganic-organic composites with a nanodispersed mineral phase. Acta Biomater, 6, 836-44.

LEEUWENBURGH, S. C., JANSEN, J. A. \& MIKOS, A. G. (2007) Functionalization of oligo(poly(ethylene glycol)fumarate) hydrogels with finely dispersed calcium phosphate nanocrystals for bone-substituting purposes. J Biomater Sci Polym Ed, 18, 1547-64.

LEGEROS, R. Z. (1991) Calcium Phosphates in Oral Biology and Medicine. IN MYERS, H. M. (Ed.) Monographs in Oral Science. San Francisco, Karger.

MARELLI, B., GHEZZI, C. E., BARRALET, J. E., BOCCACCINI, A. R. \& NAZHAT, S. N. (2010) Three-dimensional mineralization of dense nanofibrillar collagen-bioglass hybrid scaffolds. Biomacromolecules, 11, 1470-9.

MESTRES, G., LE VAN, C. \& GINEBRA, M. P. (2012) Silicon-stabilized alpha-tricalcium phosphate and its use in a calcium phosphate cement: Characterization and cell response. Acta Biomaterialia, 8, 1169-1179.

MISRA, S. K., ANSARI, T. I., VALAPPIL, S. P., MOHN, D., PHILIP, S. E., STARK, W. J., ROY, I., KNOWLES, J. C., SALIH, V. \& BOCCACCINI, A. R. (2010) Poly(3-hydroxybutyrate) multifunctional composite scaffolds for tissue engineering applications. Biomaterials, 31, 2806-2815.

MORRIS, E. R., NISHINARI, K. \& RINAUDO, M. (2012) Gelation of gellan - A review. Food Hydrocolloid, 28, 373-411.

RIVADENEIRA, J., AUDISIO, M. C., BOCCACCINI, A. R. \& GORUSTOVICH, A. A. (2013) In vitro antistaphylococcal effects of a novel $45 \mathrm{~S} 5$ bioglass/agar-gelatin biocomposite films. Journal of Applied Microbiology, 115, 604-612.

ROSSEEVA, E. V., BUDER, J., SIMON, P., SCHWARZ, U., FRANK-KAMENETSKAYA, O. V. \& KNIEP, R. (2008) Synthesis, Characterization, and Morphogenesis of Carbonated Fluorapatite-Gelatine Nanocomposites: A Complex Biomimetic Approach toward the Mineralization of Hard Tissues. Chemistry of Materials, 20, 6003-6013.

SCHUMACHER, M., LODE, A., HELTH, A. \& GELINSKY, M. (2013) A novel strontium(II)modified calcium phosphate bone cement stimulates human-bone-marrow-derived mesenchymal stem cell proliferation and osteogenic differentiation in vitro. Acta Biomaterialia, 9, 9547-9557. 
SILVA, R., BULUT, B., ROETHER, J. A., KASCHTA, J., SCHUBERT, D. W. \& BOCCACCINI, A. R. (2014) Sonochemical processing and characterization of composite materials based on soy protein and alginate containing micron-sized bioactive glass particles. Journal of Molecular Structure, 1073, 87-96.

STOOR, P., SODERLING, E. \& SALONEN, J. I. (1998) Antibacterial effects of a bioactive glass paste on oral microorganisms. Acta Odontologica Scandinavica, 56, 161-165.

VANDROVCOVA, M., JIRKA, I., NOVOTNA, K., LISA, V., FRANK, O., KOLSKA, Z., STARY, V. \& BACAKOVA, L. (2014) Interaction of Human Osteoblast-Like Saos-2 and MG-63 Cells with Thermally Oxidized Surfaces of a Titanium-Niobium Alloy. Plos One, 9.

VERMA, A., WAHI, A. K. \& PANDIT, J. K. (2012) Effect of Crosslinking with $\mathrm{Ca}++$ and $\mathrm{Zn}++$ in the Formation of Gellan Gum Gels. Lat Am J Pharm, 31, 815-820.

WITKOWSKA-ZIMNY, M., WALENKO, K., WALKIEWICZ, A. E., POJDA, Z., PRZYBYLSKI, J. \& LEWANDOWSKA-SZUMIEL, M. (2012) Effect of substrate stiffness on differentiation of umbilical cord stem cells. Acta Biochim Pol, 59, 261-4.

XIE, Z. P., ZHANG, C. Q., YI, C. Q., QIU, J. J., WANG, J. Q. \& ZHOU, J. (2008) Failure of particulate bioglass to prevent experimental staphylococcal infection of open tibial fractures. Journal of Antimicrobial Chemotherapy, 62, 1162-1163.

ZEHNDER, M., WALTIMO, N., SENER, B. \& SODERLING, E. (2006) Dentin enhances the effectiveness of bioactive glass S53P4 against a strain of Enterococcus faecalis. Oral Surgery Oral Medicine Oral Pathology Oral Radiology and Endodontics, 101, 530-535. 

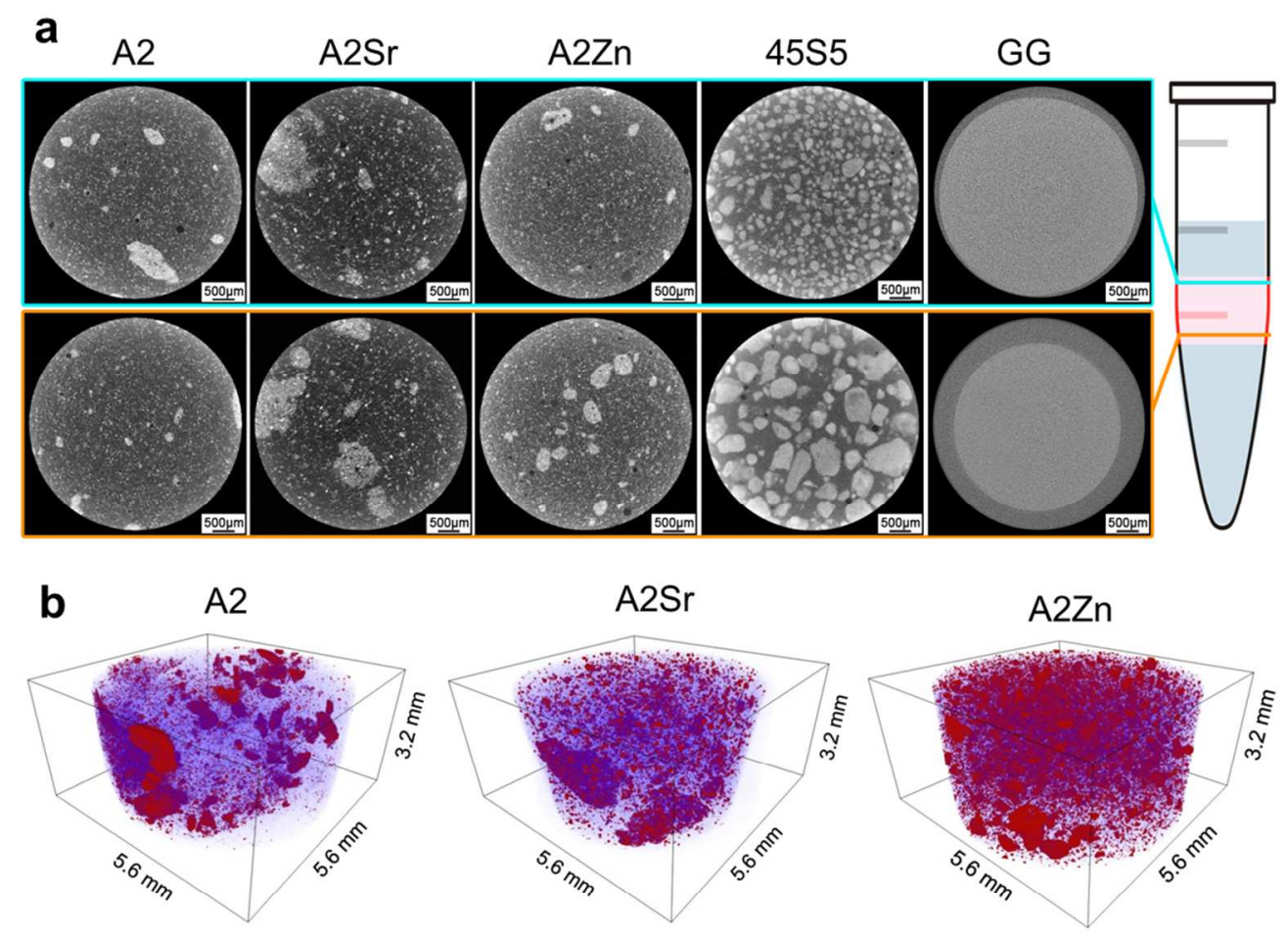

45S5
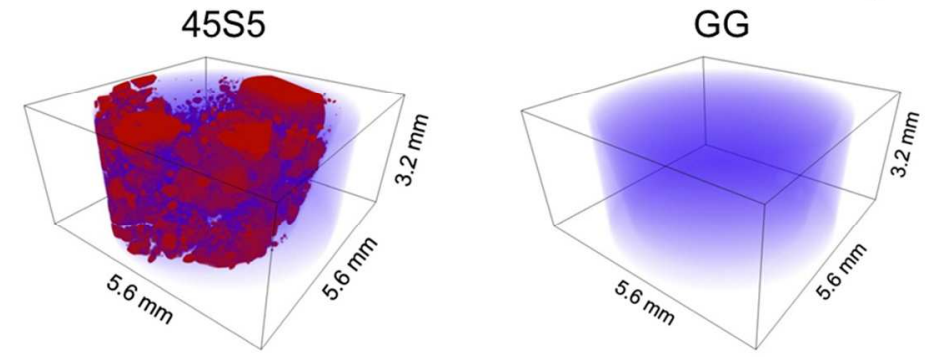

Figure 1. X-ray $\mu \mathrm{CT}$-based visualization of hydrogel-bioactive glass composites. a) Transverse sections through two different heights (close to the top and close to the bottom) for each composite type. b) 3D rendering of composite type. GG hydrogels without bioactive glass served as controls.

$99 \times 101 \mathrm{~mm}(300 \times 300$ DPI) 

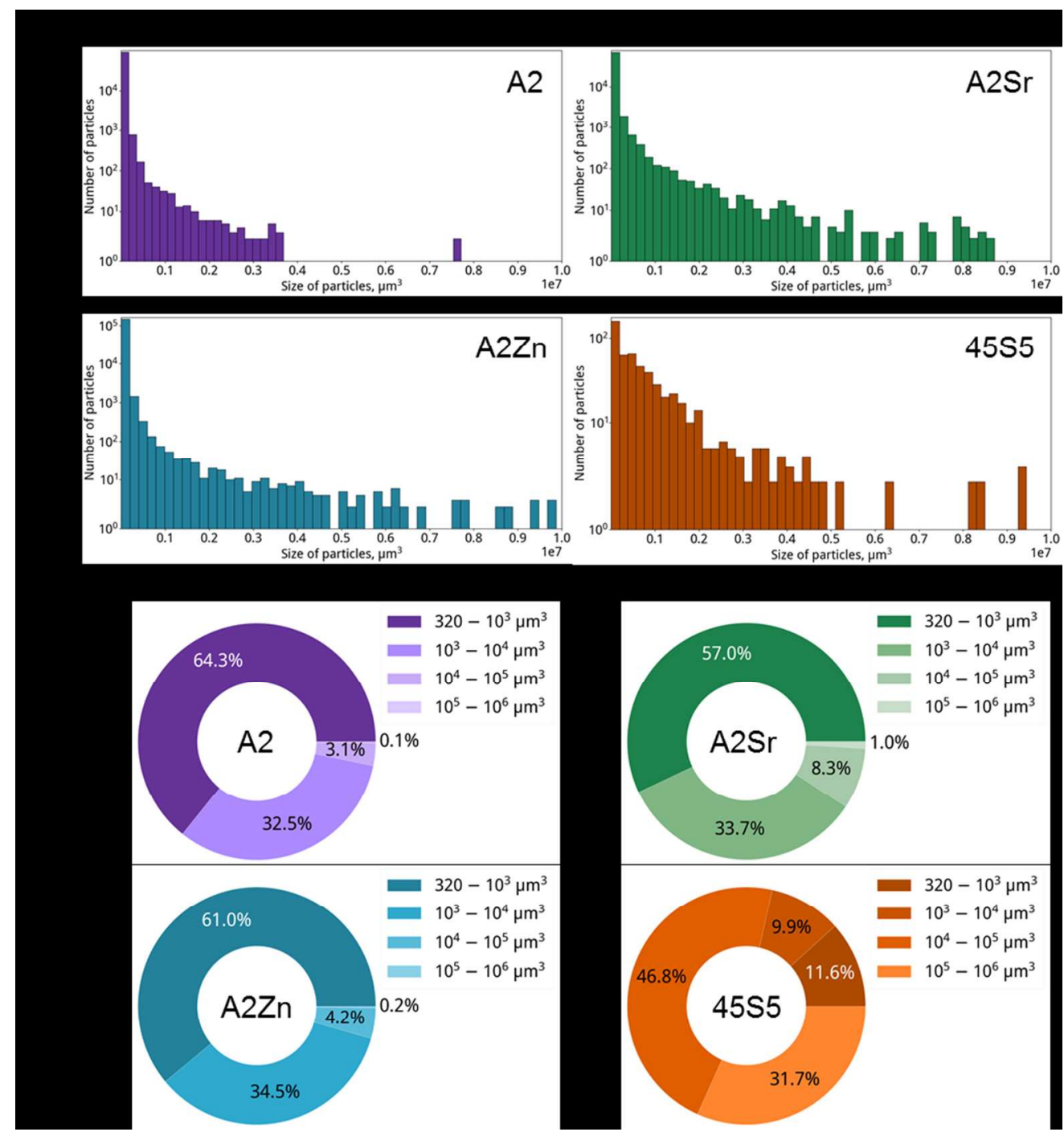

Figure 2. X-ray $\mu \mathrm{CT}$-based analysis of sizes of bioactive glass microparticles and microparticle aggregates present in composites. a) Logarithmic histograms displaying size distributions of microparticles/aggregates in composites. b) Pie charts showing percentage of a total number of microparticles/aggregates in each size region.

\section{$85 \times 91 \mathrm{~mm}(300 \times 300 \mathrm{DPI})$}



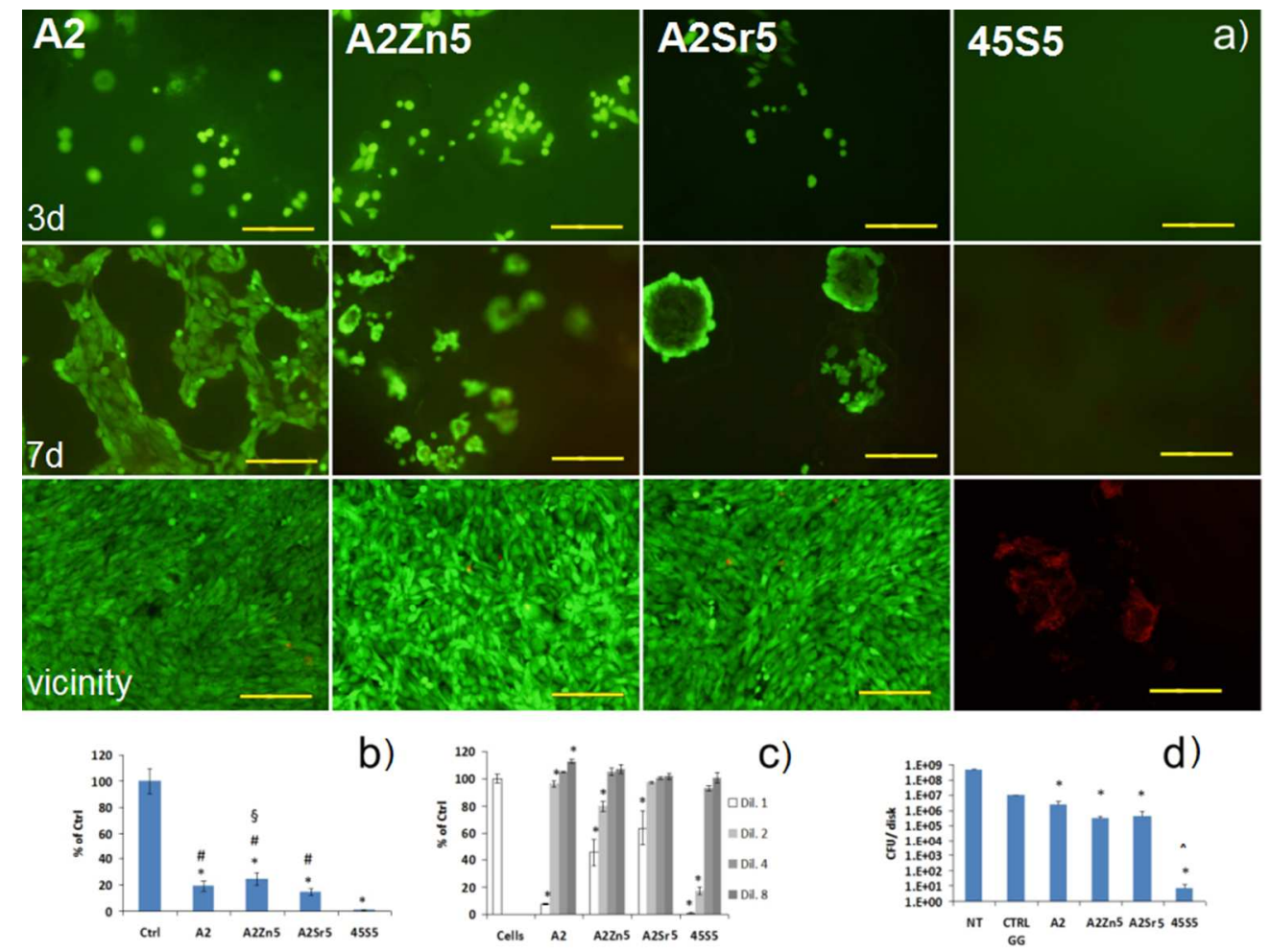

b)

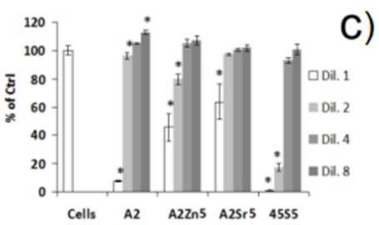

C)

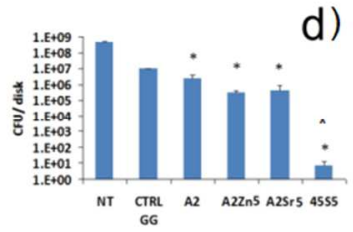

Figure 3. Cell biological and antibacterial testing of hydrogel-bioactive glass composites. a) columns, from left to right: A2, A2Zn5, A2Sr5, 45S5. Top row: MG-63 cells cultured directly on composites after 3 days. Middle row: cells cultured directly on composites after 7 days. Bottom row: cells cultured on the bottom of the same well with the composite (in eluates) for 7 days. Scale bar $=200 \mu \mathrm{m}$ in all images. b) Proliferation on composites after 7 days. Values are expressed as percentages of control values. $*: p<0.05$ relative to control (Ctrl), \#: $p<0.05$ relative to composite containing 45S5, $\S: p<0.05$ relative to composite containing A2Sr5. c) Proliferation of cells cultured for 7 days in eluates from composites, both undiluted and diluted by factors of 2, 4 and 8 . Values are expressed as percentages of control values. $*: p<0.05$ relative to control. d) Colony-forming units (CFU) of MRSA cultured in the presence of composites for $24 \mathrm{~h}$. *: $p<$

0.05 relative to GG hydrogel without bioactive glass (CTRL GG); ${ }^{\wedge}: p<0.05$ relative to $A 2, A 2 Z n 5$ and A2Sr5. Error bars show standard deviation in all sub-diagrams.

$82 \times 62 \mathrm{~mm}(300 \times 300 \mathrm{DPI})$ 


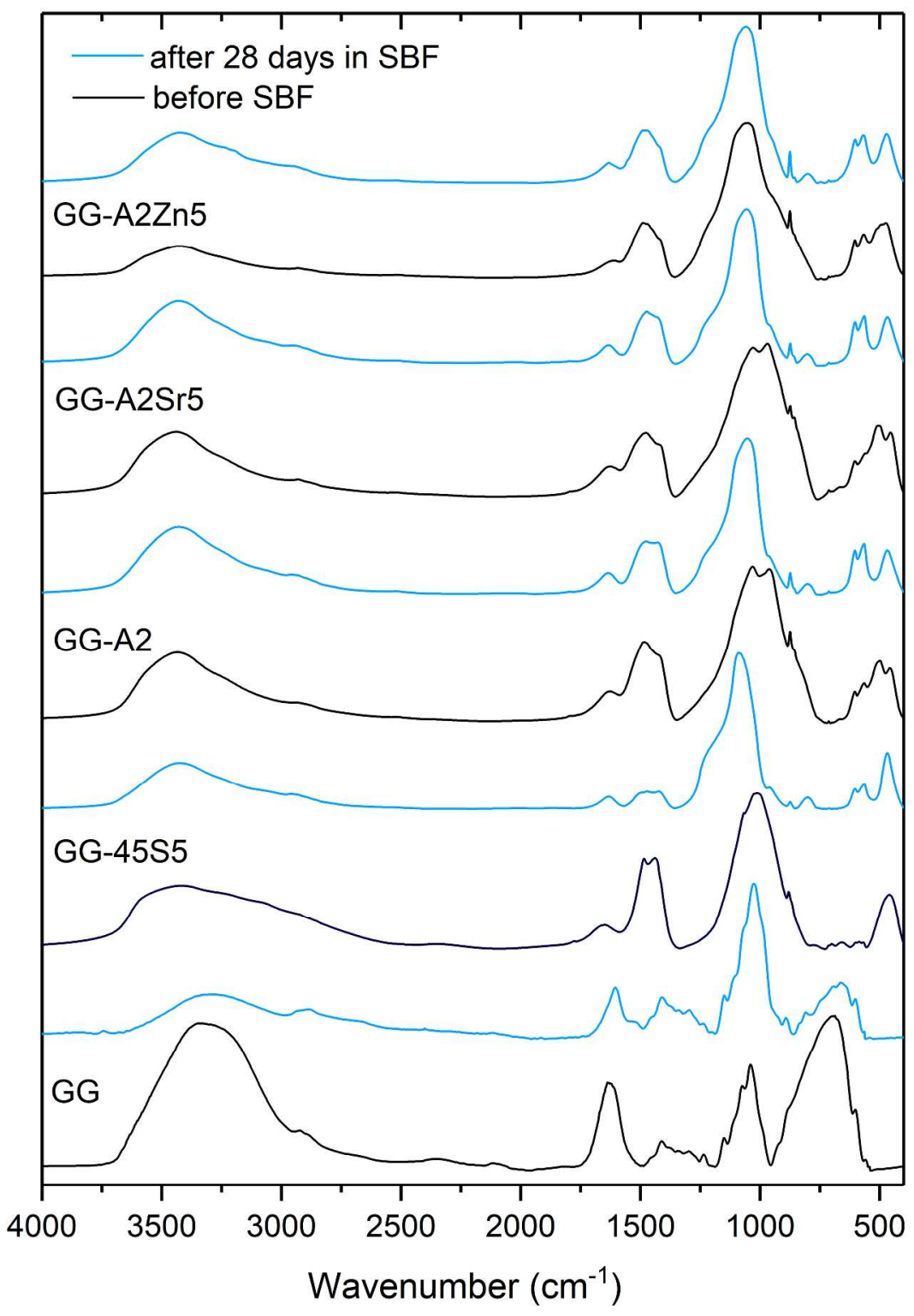

Figure 4. FTIR spectra of hydrogel-bioactive glass composites before and after incubation in SBF for 28 days. $238 \times 334 \mathrm{~mm}(300 \times 300 \mathrm{DPI})$ 


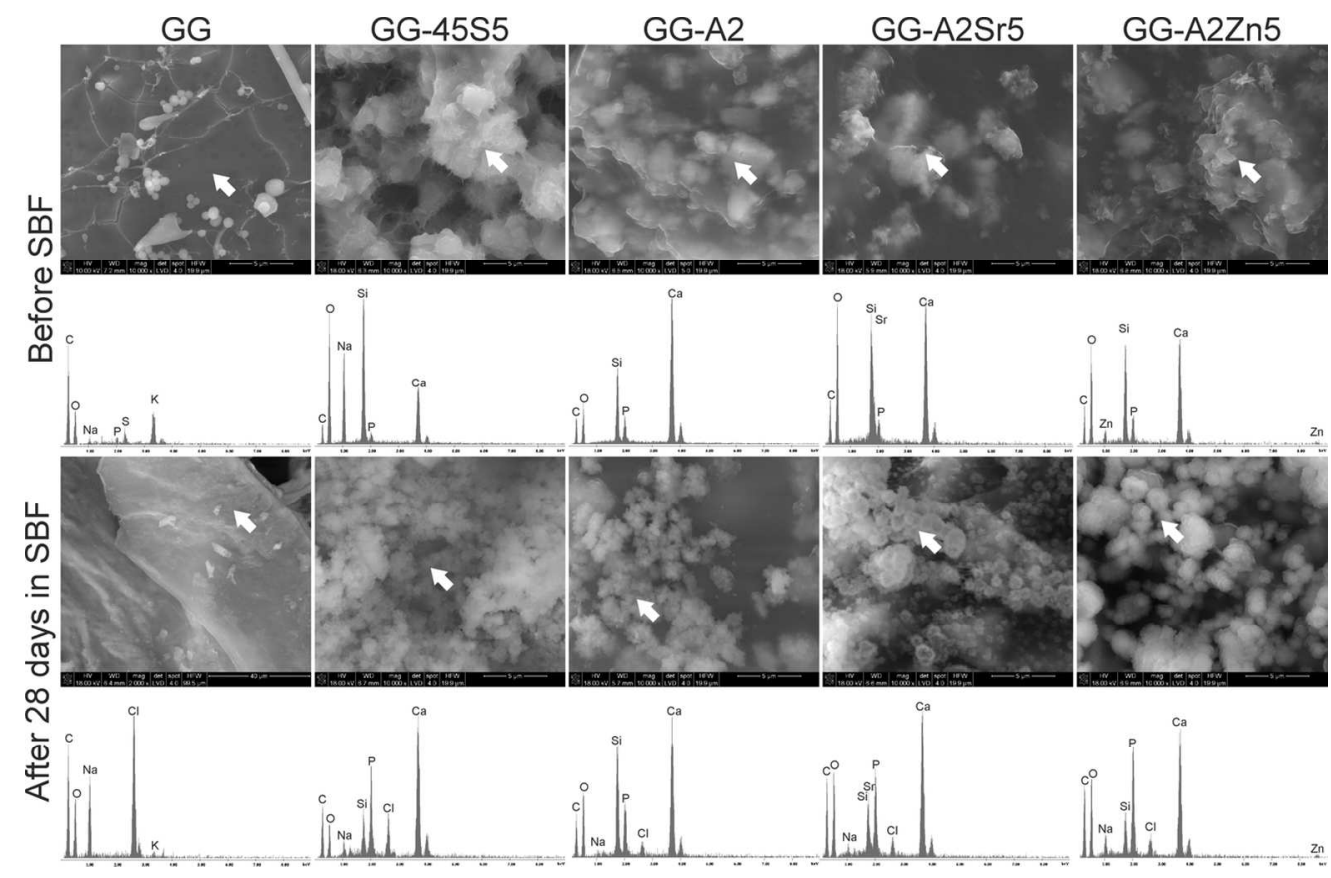

Figure 5. SEM images and EDX spectra (collected at the point indicated by arrow) of hydrogel-bioactive glass composites before and after 28-day incubation in SBF.

$127 \times 83 \mathrm{~mm}(300 \times 300 \mathrm{DPI})$ 